\title{
Redes e camadas de relacionamentos na economia: metodologias para o estudo da confiança mercantil na América Portuguesa do Antigo Regime ${ }^{1}$
}

por

\section{Tiago Luis Gil}

Universidad de Brasília

O objetivo deste trabalho é explorar a possibilidade de considerar as diferentes densidades de relações sociais que estariam associadas a diferentes graus de interação e confiança, tendo em conta a região meridional da América Portuguesa no final do século XVIII. Para realizar esta investigação, utilizamos fontes diversas, incluindo inventários post-mortem, registros paroquiais e correspondências. Para este estudo, foi criada uma base de dados centrada nas relações e interações sociais. Os resultados indicam uma aproximação estreita entre a densidade das relações e a confiança.

Palabras chave: redes sociais; economia do Antigo Regime; confiança; América Portuguesa.

O PROBLEMA

O objetivo deste trabalho é explorar a possibilidade de pensar em diferentes densidades de relacionamento que estariam associadas a diferentes graus de interação e confiança. Partindo da idéia de que é possível segmentar a vida social em camadas de relacionamentos, pretendemos explorar estas várias intensidades de relações e seus efeitos, ou seja, a forma como os agentes exploravam distintos tipos de relações para atuar naquele contexto. Nosso

\footnotetext{
${ }^{1}$ Esta pesquisa foi financiada com recursos do CNPq e da CAPES (Brasil).
} 
principal foco é na aplicação desta abordagem à pesquisa histórica, particularmente ao contexto do Antigo Regime na América Portuguesa, em finais do século XVIII e inícios do século XIX. Veremos que tal contexto possui especificidades que tornariam inviável a aplicação da noção de densidade relacional. Uma solução é apresentada, tomando em conta um sentido amplo de densidade, adotado por Bott, em paralelo à aplicação da idéia de escala.

É conhecido o papel do broker, o intermediário que liga diferentes grupos de relacionamento, que une os pontos entre grupos diferentes, então separados pela falta de um agente que os conectasse. Ampla literatura foi dedicada a este assunto, presente nos debates de rede desde os trabalhos pioneiros de Bott e de Barnes. ${ }^{2}$ Tendo em conta que os relacionamentos sociais não são homogêneos, ou seja, nem todos conhecem a todos e, aqueles que se conhecem, certamente não o fazem com a mesma intensidade, esta abordagem trata de abstrair a complexidade das relações humanas em grupos claramente definidos, tendo na figura do intermediário uma ponte entre estes grupos. Tais grupos são geralmente descritos pela literatura como "redes densas", grupos com ampla e forte interação, em comparação com os potenciais laços disponíveis a cada agente, tendo em conta outras relações mais fracas ou superficiais.

Uma parte expressiva do debate sobre densidade de redes diz respeito à sua medida, à forma como a rede potencial é efetivamente aproveitada, à intensidade das relações e à sua manutenção no tempo. ${ }^{3}$ Estas seriam as formas de classificar os agentes, que permitiriam ao investigador destacar os grupos de forma mais ou menos clara, podendo, assim, dar ênfase ao mediador ou mediadores, aqueles que conectam ambientes diferentes, grupos diversos. Restaria ainda definir o quanto cada grupo é coeso e com qual intensidade. Este tipo de investigação é associado a pesquisas realizadas diretamente com os informantes, muitas vezes através de formulários padronizados e quantificáveis, ou seja, com material empírico especificamente produzido para a pesquisa. Tendo em conta estas circunstâncias, seria possível a aplicação desta metodologia para uma pesquisa em história que tomasse o século XVIII como pano de fundo, sem que exista uma quantidade homogênea de fontes para um mesmo grupo a ser identificado ou sem fontes preparadas exclusivamente para este fim? A resposta mais direta é "não".

Se a possibilidade de adotar a metodologia de análise de densidade, tal como fora proposta por Barnes, não parece ser aplicável às fontes do século XVIII, talvez seja interessante aplicá-la ao menos metaforicamente ou, como efetivamente fez Elizabeth Bott, utilizar o conceito sem valer-se de medições

2 Barnes, 1954. Bott, 1976. Burt, 2005.

3 Barnes, 1969a. Epstein, 1969. Granovetter, 1973. 


\section{Figura 1. MAPA DO CAMINHO DAS TROPAS}

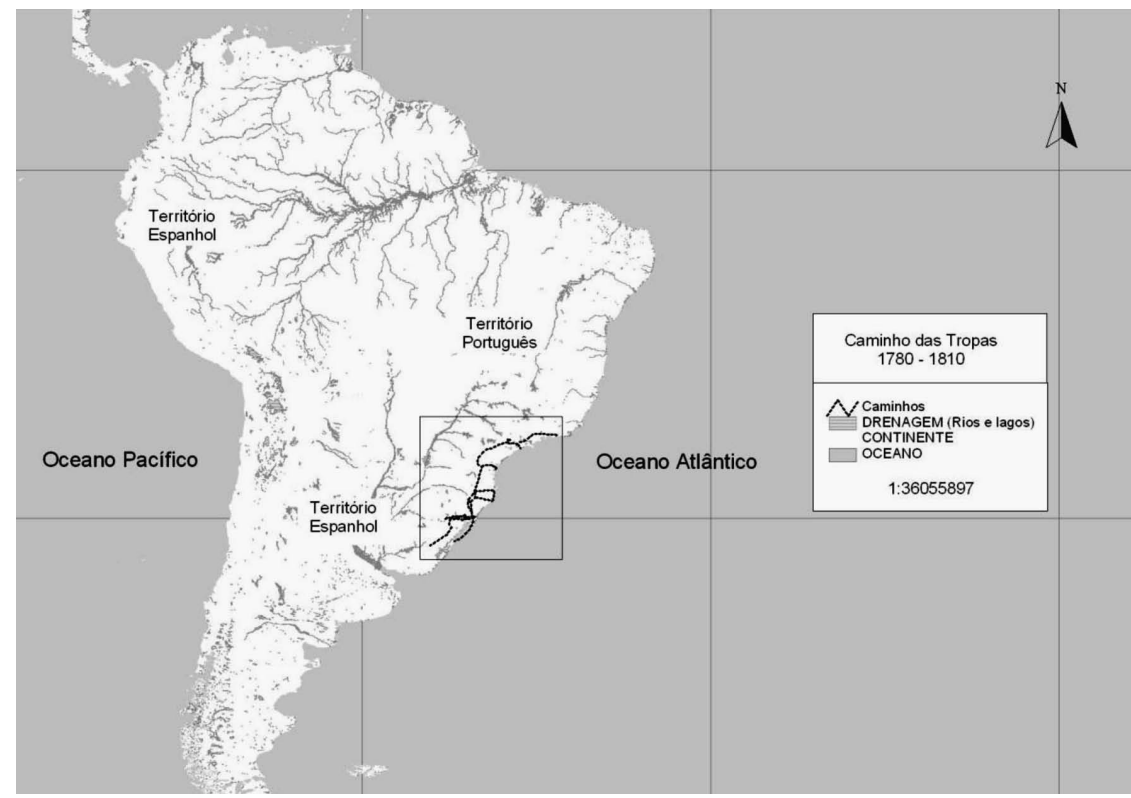

Figura 2. CAMinho das tropas (EM ESCALA MAIOR)

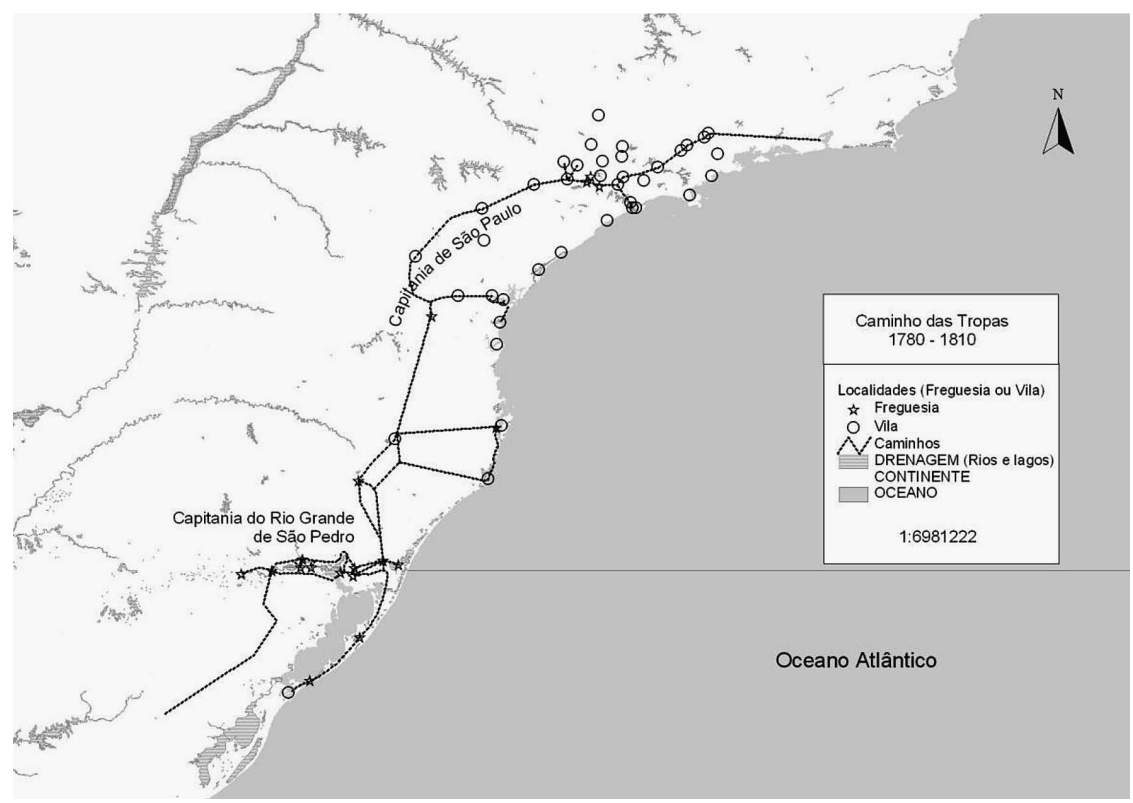

Revista de Indias, 2015, vol. LXXV, n. ${ }^{\circ}$ 264, 421-456, ISSN: 0034-8341 doi: $10.3989 /$ revindias.2015.014 
precisas, na tentativa de avaliar o impacto dos laços sociais na vida das pessoas. Neste sentido, vamos argumentar pela possibilidade de se aplicar a noção de redes densas em uma pesquisa que contemple agentes sociais que viviam no final do século XVIII no sul da América Portuguesa e que negociavam gado entre as localidades de Viamão e Sorocaba, distantes mais de $1500 \mathrm{~km}$.

Era uma rota mercantil muito longa para a escassa população daquelas regiões, as quais, como veremos, estavam relativamente isoladas no espaço. Havia uma forte produção de animais no sul da América Portuguesa, na Capitania do Rio Grande de São Pedro. A demanda por animais nas regiões centrais do Brasil colonial foi estes animais circularem aquela larga distância, através de um caminho tortuoso, montanhoso e estreito. Este fluxo durou mais de 150 anos, mas neste trabalho só tomaremos o período entre 1780 e 1810 . O comércio de animais do sul do Brasil para as Capitanias de São Paulo, Minas e Rio de Janeiro significou o abastecimento daquelas regiões de instrumentos de transporte, fundamentais para as produções locais e para o escoamento do ouro e de outros produtos coloniais. A historiografia sobre o tema é ampla, apesar de ser fundamentalmente tradicional, ou seja, baseada nas histórias do "fundador" do caminho e suas aventuras, ${ }^{4}$ sem atentar para a atuação dos negociantes, que tipo de negócios faziam, de onde eram, dentre outras questões fundamentais para compreender aquela economia. ${ }^{5}$ Veremos que a maior parte dos negociantes, ou "tropeiros", como eram chamados, provinham da Capitania de São Paulo, especialmente dos Campos de Curitiba, que ficava no meio do caminho, e que não se tratava de um grupo com grande poder de aquisição, dependendo do crédito comunitário, obtido nas vizinhanças, para garantir seus negócios.

A compreensão da forma como se davam as relações e se moldavam as redes dentro e entre as localidades nesta rota mercantil é fundamental para o entendimento de como funcionava o crédito, a confiança e a circulação de informações. Era potencialmente através destas redes que a informação fluía, criando e modificando as relações de confiança e conseqüentemente interferindo no acesso ao crédito. Certamente, em uma rota como esta, com mais de $1000 \mathrm{~km}$ de extensão, o ruído de informação e a falta de confiança poderiam ser um impeditivo dos negócios. Tendo em conta o universo abarcado pela rota, seu tamanho e o isolamento das comunidades, vamos adotar a noção de escala como referência para rever a idéia de densidade (uma única, no singular), ou melhor, como diferentes densidades podem ser vistas de acordo

\footnotetext{
${ }^{4}$ Goulart, 1961. Jacobus, 2000. Westphalen, 1995.

5 Exceção para alguns trabalhos mais recentes, que focam nos estudos quantitativos sobre o total de animais, sem, contudo, observar as relações entre os negociantes. Ver: Hameister, 2002. Marcondes e Suprinyak, 2005. Suprinyak e Restitutti, 2006
} 
com a escala observada, trabalhando, assim, com a existência de "diferentes camadas de relacionamentos no espaço em questão". Vamos argumentar que este procedimento permite verificar com maior cuidado a ação social, ${ }^{6}$ a montagem das redes e seu funcionamento. A própria literatura sobre redes permite esta adoção, como salienta Both, ao tratar das malhas estreitas e frouxas, que "uma seria dada em relação à outra, na comparação das densidades". ${ }^{7}$ Veremos que tal comparação faz mais sentido se colocada dentro de uma escala, já que permite adotar diversas vezes a oposição entre laços fortes e fracos, abusando da comparação.

\section{Proposta METODOLÓGICA}

Partindo de ampla documentação empírica, foi adotada uma postura metodológica que permitia cruzar dados prosopográficos e seriais, além de ter os relacionamentos sociais como centro da pesquisa. A forma de concretizar esta perspectiva surgiu a partir da reflexão sobre o que aporta Jean Pierre Dedieu. ${ }^{8} \mathrm{~A}$ idéia principal é a de que é possível decompor a vida dos agentes históricos em "eventos". Neste sentido, para cada ato seria criado um registro com informações como a data, o local, a interação com outro agente e um campo de detalhamento. A interação e a análise detalhada de cada ato são os pontos fortes desta forma de coletar e organizar os dados. Analisando um evento, podemos descobrir muitas coisas sobre os atores e sobre os grupos dos quais estes fazem parte.

Esta metodologia é conveniente na medida em que abre espaço para estudar a transformação dos grupos e suas diferentes dinâmicas e peculiaridades. A dinâmica de que falamos, que caracteriza as movimentações de crédito, poderia ser apreendida por esta análise minuciosa, evento por evento. Nestes termos, poderíamos "navegar" pelos atos para trás, em busca das intenções do ator e para a frente, buscando as interpretações feitas da atitude. Esta forma de conceber a investigação pode se revelar absolutamente útil numa pesquisa sobre crédito. A questão seria ver como as pessoas constroem, a partir de cada ato, uma idéia de confiança, de ganho e de solidariedade. Aperfeiçoando mais: como as diferentes idéias de confiança, ganho e solidariedade (apenas para dar alguns exemplos) que existem numa comunidade (ou numa rota mercantil) se reproduziam no dia-a-dia e se articulavam a ponto da economia funcionar?

\footnotetext{
${ }^{6}$ Inspirado em Weber, 1999 e Barth, 1981.

7 Bott, 1976.

8 Dedieu, 2005.
} 
Seria viável e enriquecedor para a pesquisa fazer uma decomposição das informações obtidas em arquivos, de forma a reorganizá-las de modo cruzado em processos cronológicos, que unissem uma diversidade de atores e atos em torno a um mesmo problema. Exemplo disso seria a agrupação de uma série de dívidas e pagamentos entre duas famílias, ao mesmo tempo em que monitoramos a ascensão/decadência de uma delas, ou os conflitos/aproximações existentes entre seus membros. Mas esta não seria a única forma de reagrupar estes fragmentos criados na investigação. A perspectiva de trabalhar a partir dos atores sociais não invalida um estudo serial. Tal perspectiva pode contribuir muito para a compreensão de algumas tendências gerais de comportamento ou, ao menos, contribuir para a formulação de hipóteses ao longo da pesquisa, em diálogo constante com as demais metodologias empregadas. Trabalhos como Centro e Periferia de uno Stato Assoluto ou "A Herança Imaterial", de Giovanni Levi, são bons exemplos da utilização articulada da história serial com a chamada micro-análise. A análise serial dos registros de compra e venda (no caso de "A Herança Imaterial") como de dotes (no caso de Centro $e$ periferia) foram importantes para a compreensão do mercado de terras e, em ambos os casos, para a compreensão dos "valores" daqueles grupos estudados, numa perfeita articulação com a metodologia proposta acima. O repertório de métodos de nossa pesquisa não poderia prescindir deste recurso. ${ }^{9}$

A adoção da metodologia de análise de redes, como aqui adotada, implicou na utilização de gráficos de relações. O gráfico é formado por nódulos (que representam as unidades), linhas (que simbolizam as relações) e setas que indicam os sentidos das ligações. De acordo com o tipo de gráfico utilizado, os desenhos e cores dos nódulos variam, o que também ocorre com o cumprimento das linhas, de forma a dar um significado visual ao que foi expresso na matriz pelo pesquisador. Todavia, tal metodologia não pretende dar conta da totalidade das relações, mas, apenas, apresentá-las de uma forma ordenada e visualmente inteligível para o investigador. Segundo Hanneman:

Una razón para la utilización de técnicas matemáticas y de grafos en el análisis de redes sociales es que permite representar la descripción de una red de manera concisa y sistemática. También posibilita el uso de ordenadores para almacenar y manipular rápidamente la información y de manera más precisa que si se hiciese manualmente. A veces son las reglas y las convenciones las que permiten que nos comuniquemos con claridad. ${ }^{10}$

Tal metodologia apresenta-se como uma importante aliada na investigação histórica. Para Boissevain, as análises de redes sociais não se constituem

${ }^{9}$ Levi, 1985; 2000.

${ }^{10}$ Hanneman, s/d Acessado em junho de 2004. 
em uma teoria, ainda que tenham implicações teóricas em sua constituição. Alguns cuidados devem ser tomados, não apenas na representação gráfica, mas, sobretudo na montagem das matrizes e na atribuição do que é ou não um relacionamento, bem como das variedades de conexões possíveis em determinado contexto. $\mathrm{O}$ fato de dois sujeitos se conhecerem é diferente de uma amizade e provoca comportamentos muito distintos. Segundo Daniel Santili, em seu estudo sobre o compadrio em Quilmes, entre 1780 e 1840, as relações de parentesco, por exemplo, devem ser matizadas:

También podemos comprobar otros lazos que asumen rasgos de parentesco como la alianza por matrimonio o el parentesco ritual establecido por el compadrazgo. Este tipo de ligamento se produce con cierto grado de elección. Pero además podemos comprobar la existencia de otro tipo de lazos más allá de la genealogía y el casamiento, como los que son visibles a través de los escritos elaborados ante los estrados judiciales, que implican un compromiso de las partes en su relación entre ellos y hacia fuera, o en los contratos comerciales. En los dos primeros casos, con matices, estamos en presencia de la comprobación de la existencia de la red pero no de su funcionamiento o de su funcionalidad para algún objetivo específico, ya que los vínculos de parentesco pueden ser precisamente nada más que eso. ${ }^{11}$

$\mathrm{Na}$ tentativa de dar conta dos problemas teórico-metodológicos expostos, construímos uma base de dados que denominamos "Sistema Malta". Foi feita tendo em vista a já mencionada proposta de Jean Pierre Dedieu, de fragmentar a vida em eventos para poder reagrupá-los de diversas maneiras. Para solucionar o problema dos variados usos e ao mesmo tempo aproximá-la das propostas de Barth, criamos um campo denominado "evento", que classifica cada ato de forma que seja possível realizar diferentes perguntas. Um mesmo evento pode ser descrito duas ou mais vezes. Para incluir registros com vistas à seriação, indicamos no campo "evento" o tipo de fenômeno reiterativo que se trata. Por outro lado, quando se refere à descrição de um "ato" ou "evento" nos sentidos apontados por Barth, é feita genericamente alguma informação no campo "evento" e descrito o ocorrido com detalhes em um campo denominado "detalhamento". Assim, os dados mais interpretativos estão juntos com os dados mais seriáveis, mas passíveis de separação pelos critérios de "rotulagem" utilizados.

\section{O CONTEXTO SOCIAL DA ROTA}

A idéia de densidade de redes ${ }^{12}$ pressupõe um conhecimento amplo das possibilidades de relacionamento dos agentes investigados, com o objetivo de

\footnotetext{
11 Santili, 2003.

12 Para esta discussão, ver Barnes, 1969 b.
} 
calcular o grau específico de densidade. A fonte por excelência que propicia este tipo de informação são questionários cuidadosamente preparados para a pesquisa, feitos a partir de diferentes metodologias, visando aspectos particulares das relações sociais. Tendo em conta o recorte que estudamos, o final do século XVIII no sul da América Portuguesa, a qual consideramos como uma economia de Antigo Regime, não dispomos de questionários e tampouco existe uma fonte que permita conhecer com cuidado o universo disponível de relações. ${ }^{13}$ Temos apenas informação parcial sobre os relacionamentos que efetivamente se deram e certamente não temos certeza sobre sua intensidade e duração. Faltam diversas peças do quebra-cabeça. Tornar-se-ia, então, praticamente impossível verificar os grupos densos existentes nesta rota e conseqüentemente os mediadores que faziam as informações circularem. ${ }^{14}$

Parece-nos, contudo, que um conhecimento, mesmo que precário, das possibilidades de relacionamento nas áreas abrangidas pela rota mercantil que estudamos seria fundamental para o entendimento da confiança no período. A opção foi tomar documentos não preparados para este fim, mas que podiam indicar, ainda que grosseiramente, tendências de comportamento e limites nas escolhas dos agentes sociais. É muito difícil encontrar fontes que nos falem do universo relacional, para além das epistolares, que tendem a se reduzir ao seleto grupo de redatores e leitores delas. Optamos pelo uso de registros de casamento, batismo e pelas dívidas mencionadas em inventários post-mortem, ou seja, pela escolha de noivos, padrinhos e credores. Uma opção destas tem limites enormes. Em primeiro lugar, tais práticas de aliança seguem regras muito específicas. Para casar, uma moça só poderia escolher um homem (se é que ela o faria), preferentemente afim com sua idade e posição social. Para padrinho, dificilmente se escolhia alguém de estatuto social inferior e para credor, certamente alguém com recursos para emprestar e com confiança no devedor. Há outras condições que não vamos explorar aqui, mas mencionaremos ao longo do texto. Com todas estas limitações, não é possível estabelecer claramente uma densidade, mas destacar alguns limites extremos dos agentes. É possível apontar grandes tendências de contatos, mas não trabalhar com grandes populações de modo preciso. Assim, optaremos por não chamar de "densidade", mas chamaremos de "mercado relacional", em clara analogia com a idéia de "mercado matrimonial", já que este também pretende apontar os limites das escolhas, mais do que o interior dos grupos.

13 Sobre a economia em questão ser classificada como de Antigo Regime, ver Fragoso, Bicalho \& Gouvêa, 2001.

${ }^{14}$ Algumas das questões teóricas aqui tratadas são baseada em: Imizcoz, 1996; 2004. 
Partindo para a documentação primária, a primeira questão que nos surgiu foi se as próprias localidades, as vilas, poderiam ser compreendidas como "redes densas", ou mercados relacionais privilegiados. A idéia partiu da avaliação do tamanho das mesmas. Sorocaba, uma das maiores povoações que abordamos, destino final da rota que vinha de Viamão, tinha, em 1803, 9.908 habitantes. Curitiba, a maior das localidades e terra da grande maioria dos tropeiros, tinha 11.334 no mesmo ano. Tanto em Sorocaba como em Curitiba, estas populações estavam distribuídas por uma grande área, agrupadas em diversas povoações, chamadas freguesias, não existindo uma grande concentração urbana. Viamão, início da rota, possuía 2.119 em 1798. Porto Alegre, junto de Viamão, possuía 3.268 habitantes no mesmo ano. Tanto para Sorocaba como para Curitiba, a documentação que utilizamos não nos permite verificar até que ponto as pequenas povoações que faziam parte da vila eram densas entre si, ainda que tal informação fosse igualmente relevante. Pudemos, contudo, avaliar até que ponto as povoações de Viamão, Porto Alegre, Curitiba e Sorocaba se serviam de outras localidades para o mercado relacional, ou se os habitantes buscavam uns aos outros para os relacionamentos.

Se observarmos as origens dos chefes de família listados em um censo de 1801, podemos começar a esboçar uma idéia dos limites geográficos do "mercado relacional" de Sorocaba.

\section{Tabela 1. Localidades de Origem dos Chefes de Família em Sorocaba} (1801)

\begin{tabular}{|l|c|c|}
\hline Local de origem & $\#$ & $\mathbf{\%}$ \\
\hline Sorocaba & 308 & 74,40 \\
\hline Itu & 22 & 5,31 \\
\hline Porto Feliz & 10 & 2,42 \\
\hline Cotia & 10 & 2,42 \\
\hline Santo Amaro & 9 & 2,17 \\
\hline São Paulo & 8 & 1,93 \\
\hline Curitiba & 5 & 1,21 \\
\hline Outros & 42 & 10,14 \\
\hline Totais & $\mathbf{4 1 4}$ & $\mathbf{1 0 0}$ \\
\hline
\end{tabular}

Fonte: Lista Nominativa de Sorocaba. 1801. Arquivo do Estado de São Paulo, Inventários Post-Mortem de Sorocaba, 1780-1800 (AESP). ${ }^{15}$

${ }^{15}$ É importante salientar que esta lista, no seu original, parece não estar completa. Maço populacional de Sorocaba, 1801. Arquivo do Estado de São Paulo. 
Se considerarmos estes dados, veremos que $82 \%$ dos chefes tem origem num raio de $30 \mathrm{~km}$, ainda que a geografia não seja o fator mais importante. Curitiba, cidade da rota mercantil, aparece antes de outras localidades mais próximas. Araçariguama e Parnaíba, apesar de próximas, não tinham uma relação tão estreita com Sorocaba como Cotia, Santo Amaro e São Paulo, que ficavam um pouco mais distantes. Da mesma forma, Itu e Porto Feliz, sendo igualmente próximas, tinham pesos completamente diferentes, sendo Itu muito mais relacionada com Sorocaba. Dados semelhantes foram encontrados por Bacellar ao analisar os casamentos em Sorocaba entre 1679 e $1830 .{ }^{16}$ Embora o recorte cronológico seja muito maior que o nosso, novamente Itu e Porto Feliz eram as principais áreas de escolha de parceiros fora de Sorocaba. O próprio autor aponta os arranjos de certos núcleos familiares extensos como principal causa da forte relação entre estas vilas. ${ }^{17}$ Assim, podemos iniciar nosso grosseiro cálculo de densidade, estimando que o "mercado relacional" no que se refere a casamentos e migrações regionais, tinha na própria vila um importante estoque de potenciais relações, ainda que Itu e Porto Feliz também fossem origem de potenciais parceiros.

Para o caso de Curitiba, temos poucos dados, sendo que alguns são de segunda mão. Por esta razão, vamos apenas citá-los, sem aplicar a mesma metodologia que utilizamos para Sorocaba e Porto Alegre. Segundo Burmeister, para o período entre 1731 e $1798,51,4 \%$ dos noivos eram nascidos em Curitiba, sendo o restante egressos de localidades da Capitania de São Paulo, principalmente de vilas situadas na rota do gado. Antonina, Paranaguá, Campo Largo, Castro, Lapa e São José. ${ }^{18}$ Note-se que das localidades especificadas, a maior parte estava em um raio de $100 \mathrm{~km}$, com exceção de Castro, que pelas rotas mais comumente usadas, distava uns $150 \mathrm{~km}$. Se tomarmos as escrituras públicas de crédito, dívidas e obrigações, temos que de um total de 358 referências espaciais que pudemos encontrar, 289 (4/5) faziam referência à própria vila, especificamente. Cerca de $5 \%$ indicavam São José como uma localidade relevante naquelas fontes. Paranaguá ocupava a terceira posição, seguida do Rio de Janeiro, ambas com pouco mais de $2 \%$. Esta é a fatia "relacional" dos vínculos comerciais de Curitiba com o comércio atlântico de cabotagem entre Paranaguá e Rio de Janeiro. Em quinto lugar vinha a pequena, mas prestigiosa, Capela do Tamanduá, distante $50 \mathrm{~km}$ de Curitiba, onde poucos e ricos fazendeiros com suas famílias e escravarias formavam a população. Lages e o "continente do sul" não somavam $1 \%$ das referências

\footnotetext{
16 Bacellar, 2001.

17 Bacellar, 1997.

18 Burmeister, 1981.
} 
nas escrituras. ${ }^{19}$ Mesmo com a precariedade destes dados, é possível verificar alguma "densidade" no conjunto formado por Curitiba e seus arredores, tanto para o casamento como para dívidas.

Para a localidade de Viamão, utilizamos os Registros de Batismos, que podem nos fornecer informações relevantes sobre a geografia das relações. ${ }^{20}$ Ao observarmos o critério espacial de seleção de padrinhos, pela residência no momento do batismo, observamos que do total dos 1.944 registros, 1.865 (97\%) era da própria localidade ou de áreas muito próximas, num raio de $15 \mathrm{~km} .{ }^{21}$ Outros $2 \%$ era de padrinhos vindos de localidades vizinhas, como Porto Alegre, Anjos e Santo Antonio da Patrulha, num raio de $40 \mathrm{~km}$. As localidades mais distantes, nas quais estariam Santo Amaro, Rio Pardo e Rio Grande (ainda dentro do continente do Rio Grande) e talvez Paranaguá, ${ }^{22}$ somadas àqueles casos que não pude identificar o agente (14 casos), chegariam a $1 \%$, num total de dezenove casos. Estes dados nos sugerem pensar que o mercado relacional de Viamão inclui Porto Alegre, Anjos e Santo Antonio da Patrulha, em sua parte mais central, tendo como "periferia" a região do Caí e Triunfo, estas últimas, povoadas originalmente por famílias vindas de Viamão. ${ }^{23}$

Tomando o mesmo procedimento para Porto Alegre, com os registros de batismos de livres e escravos entre 1772 e 1797, encontramos resultados próximos, mas com algumas diferenças. Entre mais de 2000 registros, dentre os quais a grande maioria não fazia referência à localidade, encontramos 24 referências à "residência" de padrinhos além de 58 padrinhos por procuração. Dentre aqueles 24, 11 eram de Porto Alegre, 3 de Viamão, 3 do Rio dos Sinos (proximidades de Gravataí), 3 do Rio Grande, 2 de Triunfo, 1 de São Paulo e 1 do Rio de Janeiro. Dentre os padrinhos por procuração, fiz o mesmo procedimento executado para Viamão, ou seja, rastrear nas bases de dados. Encontramos 32 dos 58, dos quais 10 eram de Porto Alegre, 7 de Rio

${ }^{19}$ Livros de Notas do Primeiro Tabelionato de Curitiba, Livro 20, 21, 22, 23, 24, 25 , 26, 27, 28 e 29, Arquivo do Centro de Documentação e Pesquisa de História dos Domínios Portugueses, Curitiba-Panamá.

${ }^{20}$ Livro de Batismos n.04, Viamão, Arquivo da Cúria Metropolitana de Porto Alegre.

${ }^{21}$ Este cálculo esbarra em alguns problemas sérios, dos quais o leitor deve ser avisado. Consideramos que a grande maioria dos padrinhos para os quais não havia informação de localidade eram de Viamão ou das proximidades. Não buscamos cada um dos padrinhos em diversas fontes, o que seria mais rigoroso. Mas consideramos que aqueles registros que informavam a localização, somados àqueles que foram feitos com procuração, seria uma amostra que tenderia a contrariar a hipótese que estou apontando, a de que o espaço relacional de Viamão era restrito e que apenas algumas poucas pessoas podiam estender suas relações para mais além.

${ }^{22}$ Tratava-se de um nome bastante comum.

${ }^{23}$ Kühn, 2006. 
Grande, 4 dos Anjos, 3 de Triunfo, 3 do Rio de Janeiro e 2 do Caí. Viamão, Lages e Curitiba tinham, cada uma, um. Este procedimento metodológico, de utilizar fontes seriadas para estimar o alcance geográfico do que chamamos de "mercado relacional", nos ajudou a mapear os limites de cada localidade. Tanto em Porto Alegre como em Viamão havia um relevante estoque de potenciais parceiros para construção de redes, e assim "a oferta e procura de contatos encontrava resposta na própria localidade", na maior parte das vezes. Contudo, Viamão também se fazia sentir em Porto Alegre e esta última na primeira, assim como Anjos, Triunfo e Rio Grande também faziam parte deste universo mais acessível de relacionamentos.

Se observamos apenas os registros de dívidas das principais localidades à margem da rota mercantil, o resultado não é diferente, e coincide com o observados para batismos e casamentos. Antes de continuar, importa informa sobre algumas características do mercado de crédito neste contexto, ainda que este seja um dos resultados da pesquisa. As principais fontes de crédito disponíveis são os mercadores, aqueles de grande escala, sediados no Rio de Janeiro, e os pequenos negociantes das mesmas comunidades. Não identificamos fornecimento de crédito externo e nem mesmo a Igreja tem um papel central aqui. Os juros, quando cobrados, ficam ao redor do estabelecimento pela lei, 5\%, e não encontrei indícios significativos de cobranças indevidas, salvo poucos casos pontuais. A maior parte do crédito é miúdo, oferecido e tomado dentro das mesmas comunidades.

Analisando as dívidas de inventários post-mortem de Sorocaba (entre 1780 e 1800) é possível verificar que as poucas dívidas que fazem referência a credores/devedores de outras localidades se referem, na grande maioria, a povoados bastante próximos daquela vila, como São Roque, Itu e Porto Feliz, assim como à cidade de São Paulo. O mesmo fenômeno pode ser visto na Porto Alegre da época, quando os principais interlocutores do crédito daquela freguesia parecem estar todos na mesma localidade, com poucas exceções, a maioria localizada em lugares próximos, como Rio Pardo, Patrulha, Cima da Serra, Rio Grande e Triunfo. Isso sugere que o estoque de credores tinha grande correlação com o estoque de devedores na mesma localidade, as necessidades locais eram equiparáveis. Observando apenas os débitos e créditos exteriores às comunidades, há uma forte tendência para que o fator geográfico exerça alguma influência, mas matizada pela demografia. Uma cidade como São Paulo oferecia mais recursos, mais crédito, à vila de Sorocaba que a vizinha Parnaíba.

Somando as dívidas de inventários e escrituras de Porto Alegre, Curitiba e Sorocaba, que utilizamos até aqui, temos um total de 2.674 dívidas, manipuladas por 2.291 agentes, entre credores e devedores (muitos estão nas duas posi- 
Figura 3. Rede De CRedores e devedores de Sorocaba (1780-1790)

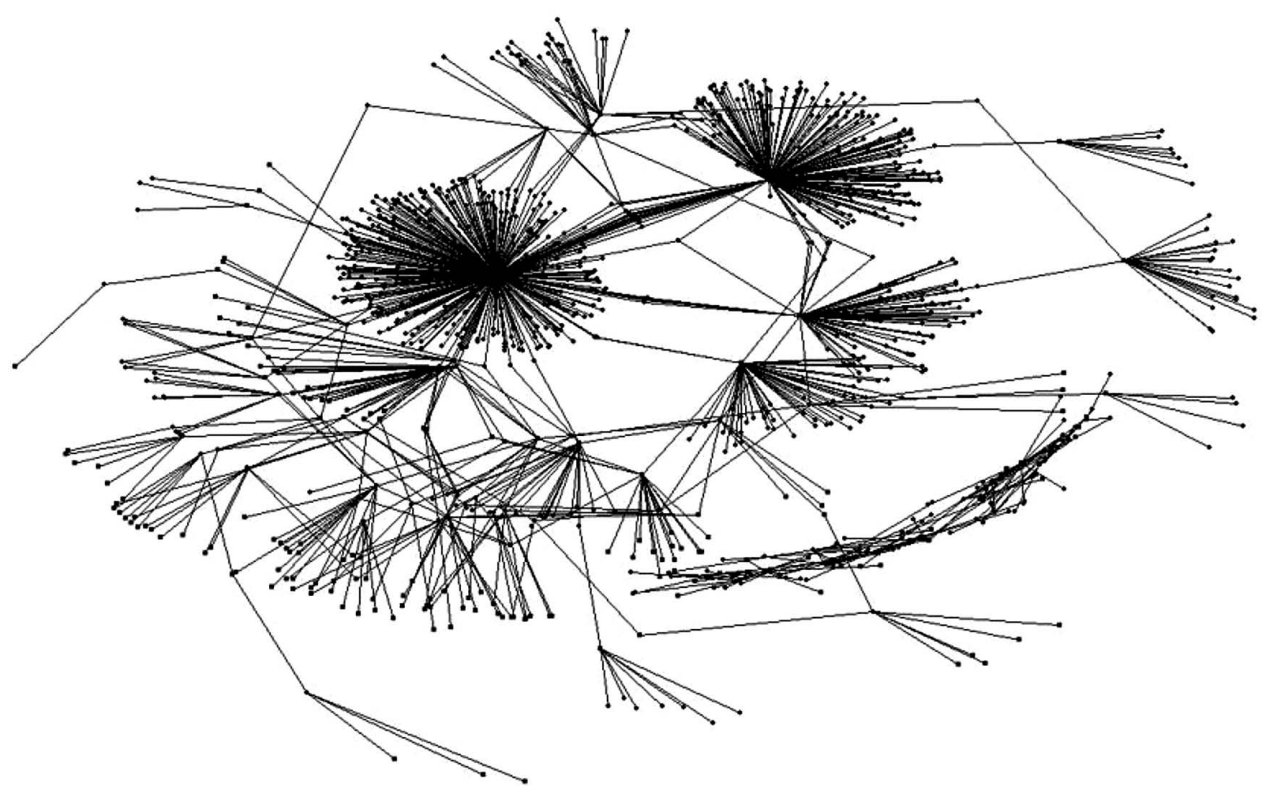

Fonte: Dívidas dos Inventários de Sorocaba, AESP.

ções). Em Porto Alegre, com uma população que variou entre 1.512 habitantes (em 1780) e 3268 (em 1.798), temos um total de 974 dívidas de inventário, ${ }^{24}$ manipuladas por 832 agentes ao longo de todo este período, sendo que alguns eram de fora da localidade. Em Sorocaba o problema era análogo: as 1422 dívidas de inventários entre 1780 e 1799 foram realizadas por 1086 pessoas, enquanto a população local variou entre 6815 (em 1780) e 7177 (em 1798). Ou seja, em ambos os casos, há uma grande concentração das operações de crédito dentro de um grupo reduzido, atuando como credores e devedores. ${ }^{25}$

Mas este grupo podia ser ainda mais seleto. Em Sorocaba, $72 \%$ dos agentes do crédito (credores e/ou devedores) participaram de uma única transação, $15,7 \%$ participaram de duas transações, 4,5 participaram de três operações. Temos assim um pequeno grupo de $7 \%$ dos agentes do crédito que participaram de diversas operações. Apenas no inventário de Paulino Aires de Aguirre, por exemplo, se contavam 431 operações e no de Andreza de Almeida Pacheco,

\footnotetext{
${ }^{24}$ Dívidas listadas em inventários post-mortem. Para Porto Alegre, tomamos o período de tempo entre 1780 e 1800 .

${ }^{25}$ Para Sorocaba, o recorte foi entre 1780 e 1800.
} 
292. Na imagem abaixo, podemos ver o conjunto de todas as relações de crédito realizadas em Sorocaba e registradas em inventários daquela vila entre 1780 e 1790. Há uma grande quantidade de agentes interagindo neste mercado, mas é possível perceber que alguns personagens têm posições centrais naquela economia, enquanto um grupo enorme de pessoas ocupa a periferia do gráfico, interagindo com apenas uma pessoa.

A primeira observação seria salientar que alguns "comandam" o crédito na localidade, provavelmente negociantes e provavelmente em vendas fiadas. Mas se retirarmos da visualização aqueles que fizeram apenas uma transação, podemos verificar um cenário diferente, onde a densidade comunitária é mais notória (figura 4).

Nesta visualização, os agentes de crédito (credores e devedores) aparecem conectados entre si direta e indiretamente inúmeras vezes, reforçando a idéia de uma densidade local, a qual ficou sugerida na análise inicial com dados de casamentos e de um censo da época (tabela 1). Todos os pontos que aparecem no gráfico acima eram habitantes da mesma Sorocaba, ou seja, aquela vila possuía um mercado relacional para o crédito que garantia o funcionamento da

Figura 4. Rede de CRedores e deVedores de Sorocaba (1780-1790 - NÚCLEO DENSO)

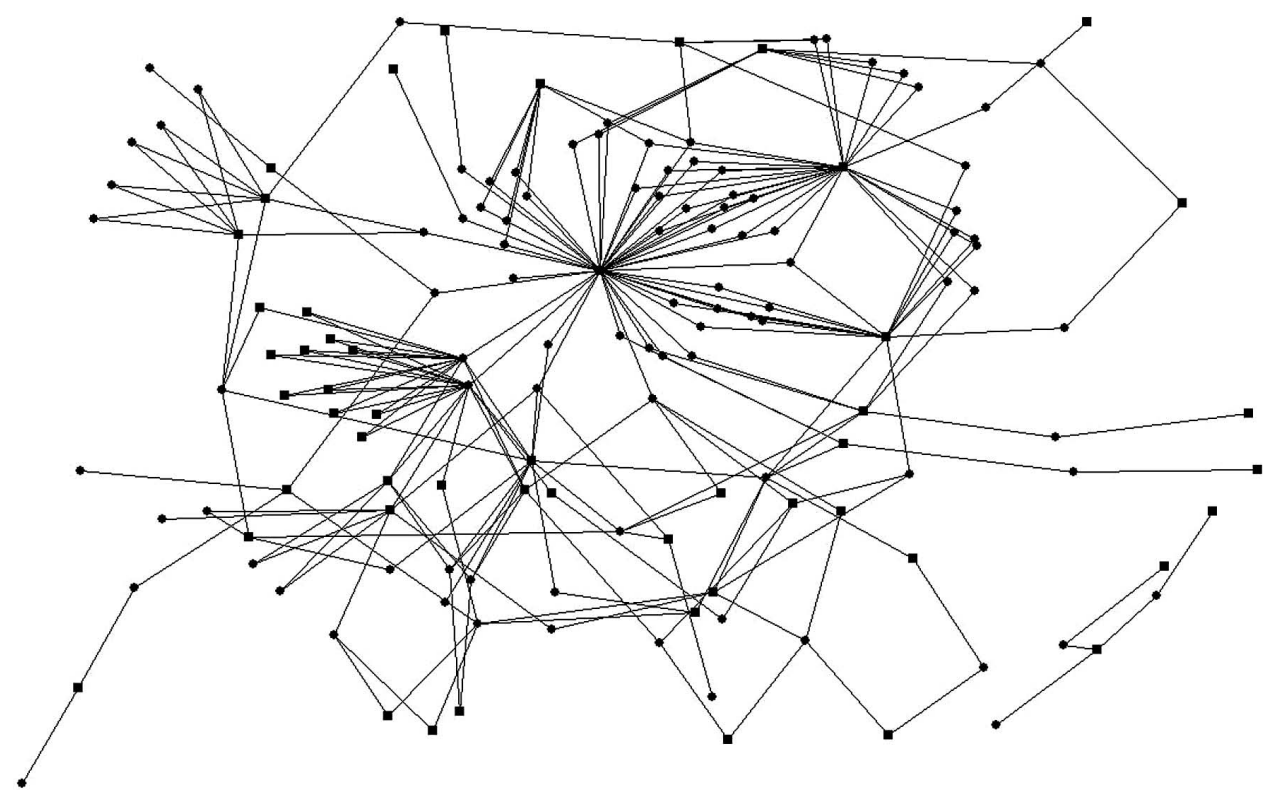

Fonte: Dívidas dos Inventários de Sorocaba, AESP. 
economia. Contudo, não queremos ficar nesta constatação. Parece-nos mais relevante destacar que, utilizando os registros de crédito e dívidas dos inventários post-mortem, é possível verificar pelo menos duas "camadas de relacionamentos", duas densidades dentro da mesma vila. Sorocaba era capaz de fornecer crédito aos seus habitantes, mas dentro do grupo de pessoas que estava neste mercado, havia um ainda mais recorrente, mais reiterativo, formado por um pequeno grupo que atuava diversas vezes emprestando e tomando emprestado. Poderíamos ir mais longe e salientar que dentro deste grupo formado por quem emprestava e tomava emprestado com regularidade, há grupos familiares que certamente tinham uma densidade ainda maior, ou seja, faziam parte de um mercado relacional privilegiado para o crédito ou para outras formas de prestação tidas como naturais entre familiares naquele tempo. ${ }^{26}$

Figura 5. Rede de Credores e devedores de Porto Alegre (1770-1780)

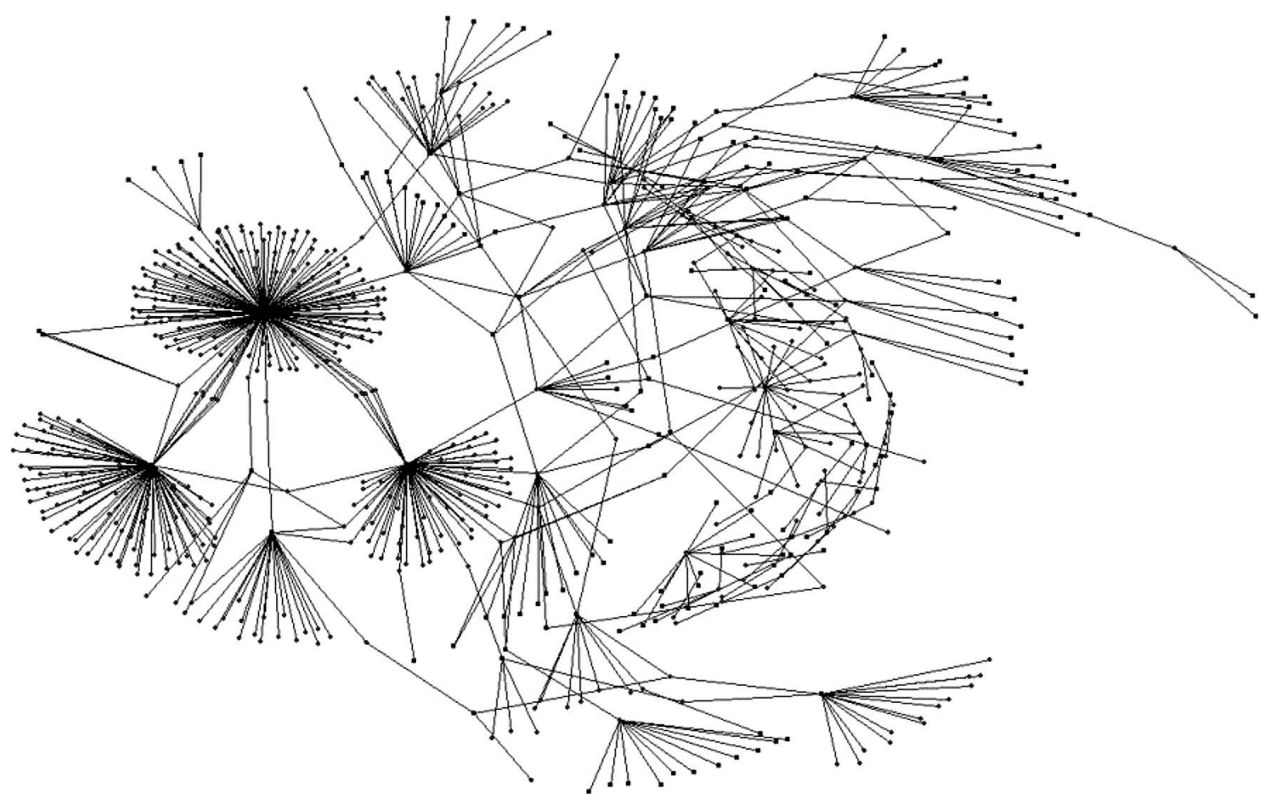

Fonte: Dívidas dos Inventários do Primeiro Cartório de Órfãos e Ausentes de Porto Alegre, APERGS.

${ }^{26}$ Não descartamos a falha da lógica familiar em alguma circunstância, mas são conhecidas as normas próprias do comportamento familiar independente do que considerassem família àquele tempo. Sobre isso, ver Clavero, 1990. 
Figura 6. Rede de credores e devedores de Porto Alegre (1780-1790)

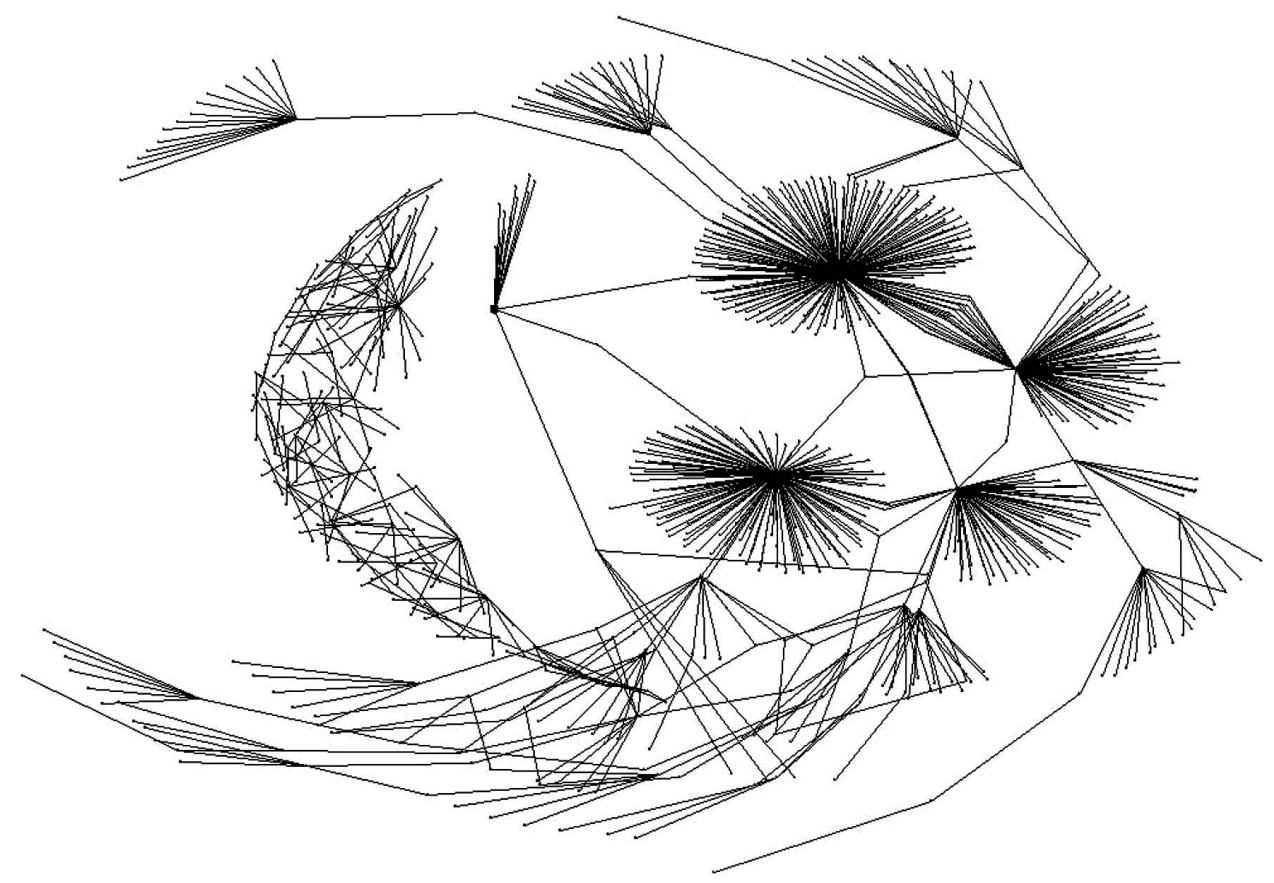

Fonte: Dívidas dos Inventários do Primeiro Cartório de Órfãos e Ausentes de Porto Alegre, APERGS.

Encontramos algo semelhante em Porto Alegre na época, próxima à Viamão e onde eram produzidos os inventários de toda a região, inclusive desta última localidade: $76,2 \%$ dos agentes do crédito participaram de até duas transações; 12,8 participaram de três ou quatro operações. Apenas 4,44\% dos agentes do crédito participaram de sete ou mais operações. Nesta localidade, no inventário de José dos Santos Loureiro se contavam 272 dívidas ativas e passivas, e 141 no de José Alves Veludo. E todos os quatro eram negociantes de loja, o que os colocava numa posição central no mercado de crédito.

Com isso não queremos concluir que eles controlavam o crédito em suas localidades, conclusão já apontada por diversos outros autores. ${ }^{27} \mathrm{O}$ que queremos salientar é que tanto estes quatro negociantes como outros tantos que faziam parte daquela pequena fração formavam uma corrente de débitos e créditos que fez, historicamente, os recursos circularem naquelas localidades.

27 Braudel, 1998. Florentino e Fragoso, 1996. Sampaio, 2003. 
$\mathrm{Na}$ verdade, a maior parte destes agentes estava em ambas as posições, credor e devedor, mas em diferentes momentos de suas vidas. Em certas épocas se destacavam outorgando e em outras, recebendo. Os ativos e passivos que pudemos encontrar nos inventários e nas escrituras permitem visualizar um mercado de crédito muito particular, manipulado por um pequeno grupo que fazia os recursos circularem entre si ao longo dos anos, uma "dança das cadeiras" da liquidez, e era isso o que permitia àquelas localidades relativamente pobres e com pouco numerário manterem sua economia em funcionamento.

Tal como em Sorocaba, em Porto Alegre e na região de Viamão é possível verificar outra densidade, ou melhor, um mercado de crédito mais recorrente dentro do mercado de crédito, com aqueles agentes que participaram de diversos negócios ao longo de um período de tempo, a partir dos registros de dívidas dos inventários post-mortem.

Nas figuras 5 e 6, é possível encontrar uma outra "camada", ainda mais densa, dentro do mercado de crédito "local". Se as relações de crédito eram

Figura 7. Rede de credores e devedores de Porto Alegre (1770-1780 - NÚCLEO DENSO).

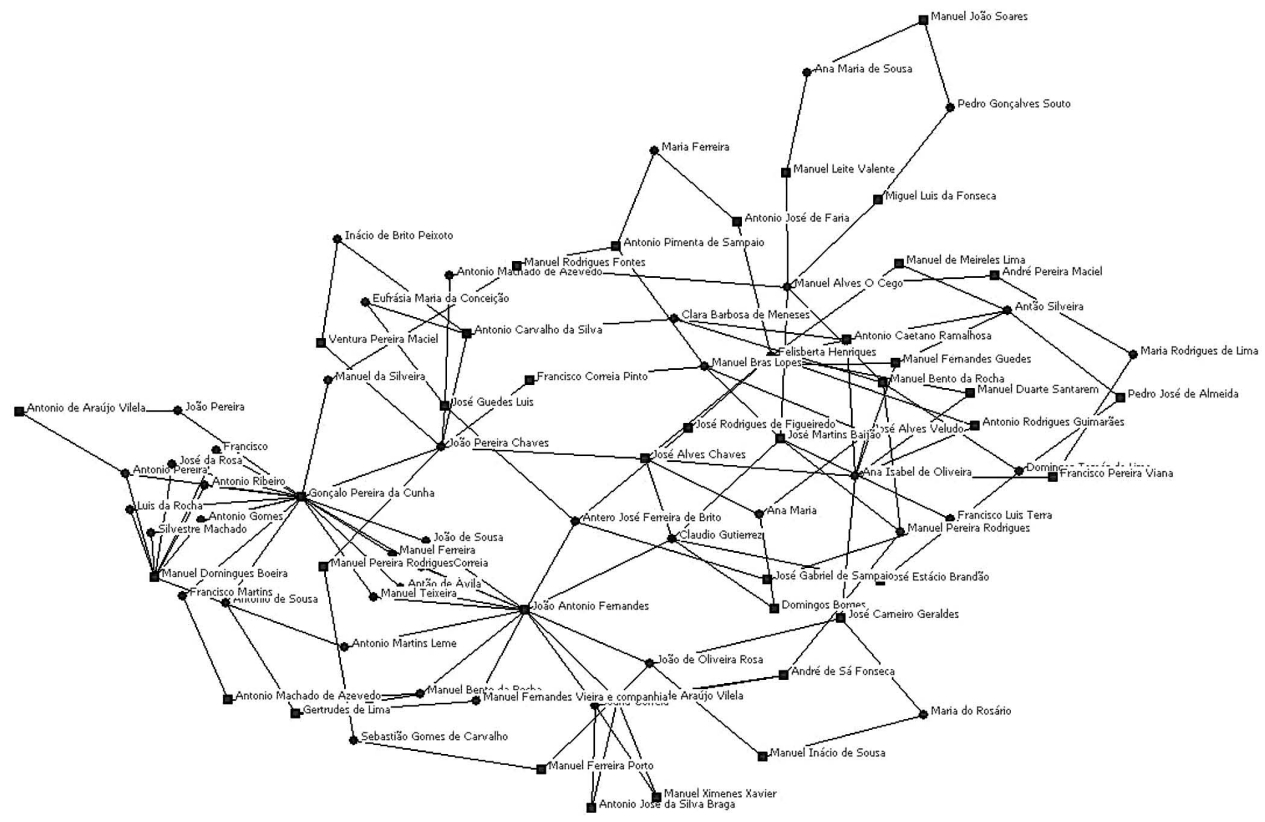

Fonte: Dívidas dos Inventários do Primeiro Cartório de Órfãos e Ausentes de Porto Alegre, APERGS. 
Figura 8. Rede de credores e devedores de Porto Alegre (1780-1790 - NÚCLEO DENSO)

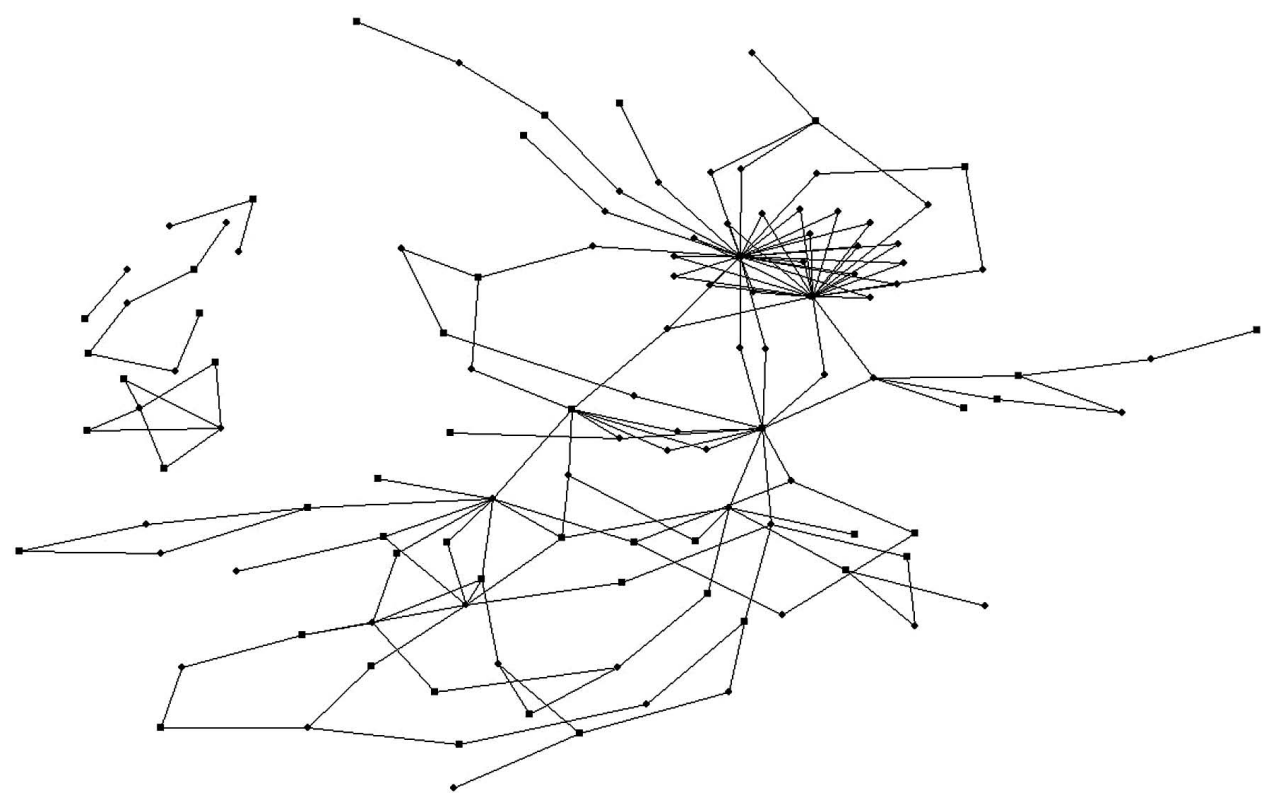

Fonte: Dívidas dos Inventários do Primeiro Cartório de Órfãos e Ausentes de Porto Alegre, APERGS.

endógenas, se o mercado relacional do crédito tinha reflexo dentro da própria localidade, havia um grupo que manipulava estas operações com mais freqüência, de modo que uns estavam conectados aos outros direta e indiretamente de múltiplas formas.

Parece-nos que havia, mesmo entre as dívidas, uma predominância daquilo que estamos chamando de densidade local, sendo possível encontrar um grupo ainda mais denso, ou um mercado ainda mais seleto, ao alternar a escala de observação, removendo credores e devedores de uma única experiência. Se não excluímos estes últimos, tomando todas as dívidas, surgem agentes de outras regiões e lugares. Para Viamão, as dívidas aumentaram a área total de relacionamentos que vimos para os batismos, acrescentando importância a certas localidades. Rio Pardo aparece com maior destaque, e mais do que a vila do Rio Grande, enquanto o Rio de Janeiro aparece com maior força, superior a São Paulo. Isso nos sugere novamente o quão seletivo é o mercado relacional. Mais do que isso, aparte toda a economia das tropas de animais que rumavam para Curitiba, o mercado relacional do 
Figura 9. Escala 1, DUAS “CAMAdAs” lOCAIS, A PARTIR DAS RElaÇÕES DE CRÉDITO E DÍVIDA
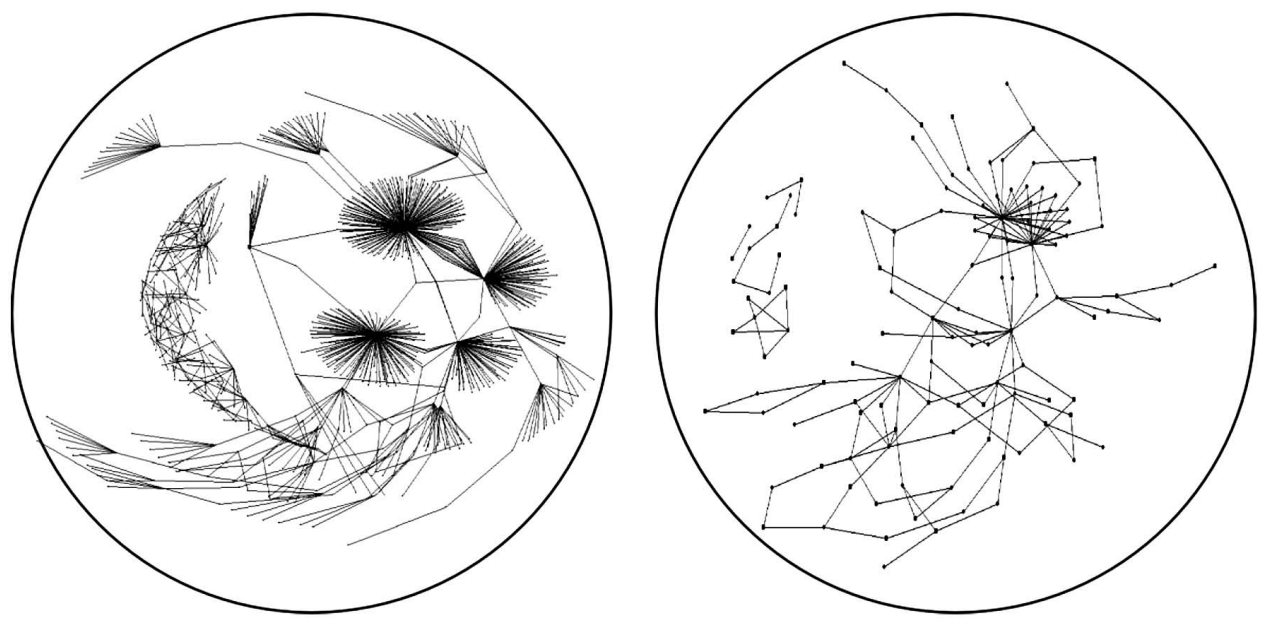

Obs.: À direita, o total de relações de crédito, à esquerda, apenas aqueles agentes com mais de uma participação no mercado de crédito local. Importa neste caso notar que uma mesma escala de observação permite visualizar duas camadas diferentes, dadas pelas características econômicas locais.

Figura 10. Escala 2 e 3, Densidades Regionais de Relacionamentos, Salientando as relações pessoais entre Sorocaba, Itu e Porto Feliz E AQUELAS SUPRA-REGIONAIS

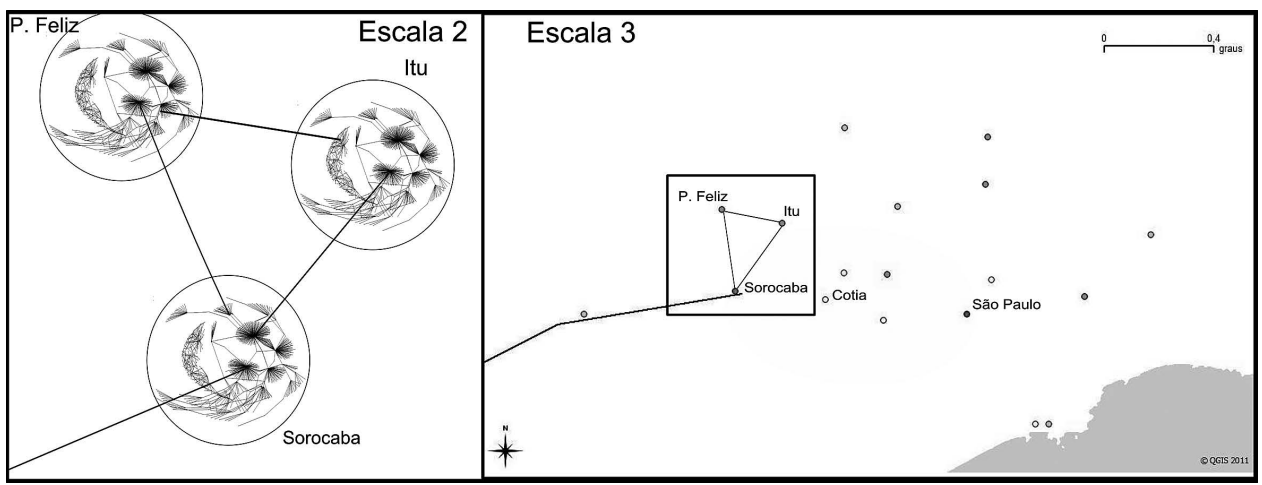


Figura 11. Escala 4, DENSIDAde da Rota, COM O NÚMERO 1 INDiCANDO o “Cluster" de São Paulo, dentro do qual havia o "Cluster" da região de Sorocaba, Itu e Porto Feliz

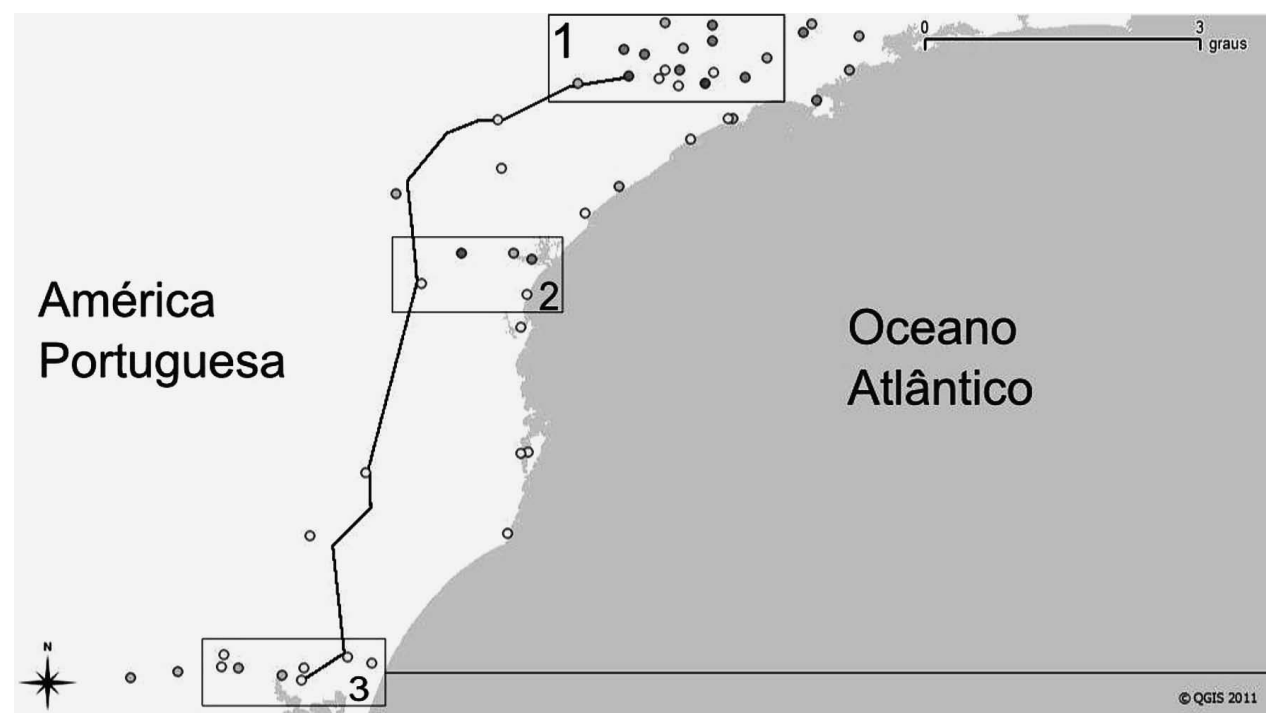

Obs.: O número 2 indica o "cluster" de Curitiba, não explorado neste texto. O número 3 indica o "cluster" de Porto Alegre, Viamão e região, onde as densidades também variam de acordo com a escala de observação.

Viamão, podendo incluir aí Triunfo, seguia outros vetores, mais restritos, mas com alguma ligação ao Rio de Janeiro. De qualquer forma, mesmo distantes, São Paulo e Sorocaba ainda mantinham certa presença, apesar já um tanto borrada. O mesmo se pode dizer para Curitiba e Laguna, que ainda se sentiam de longe.

Em Sorocaba, igualmente o Rio de Janeiro se fazia sentir em um par de dívidas. Isso se dá pelo fato de aquele porto ser o principal fornecedor de escravos de toda a região, de Sorocaba ao Viamão, e muitas compras de cativos se faziam a crédito. Nesta vila, contudo, São Paulo se fazia sentir de perto no mercado de crédito, já que era naquela cidade que estavam os grandes negociantes regionais. Neste sentido, é preciso matizar a "densidade local". Se notamos que a grande maioria dos relacionamentos acontecia dentro das vilas e comunidades, também foi possível ver que localidades vizinhas vinham logo atrás, variando conforme a fonte que tomamos, se batismos, casamentos ou dívidas. Uma localidade como Sorocaba, destino dos animais na rota mercantil, mantinha forte relação com Itu e Porto Feliz, os dois locais mais 
próximos. Em uma terceira camada, encontramos Cotia, Santo Amaro e São Paulo, populosas, mas um pouco mais distantes.

Deste modo, acreditamos que é possível compreender a região de Sorocaba, Itu e Porto Feliz como um "cluster", por sua vez, dentro de um "cluster" maior, incluindo diversas vilas ao redor da grande cidade daquela região, São Paulo. É neste sentido que acreditamos na validade do uso de diferentes escalas para observar o limite dos agentes na construção de redes, neste caso, com atenção para os aspectos espaciais. Entendemos, assim, a comunidade de Sorocaba como uma rede densa na comparação com seu cluster mais imediato, constituído também por Itu e Porto Feliz. Este cluster, por sua vez, "seria uma rede densa" (ou mercado relacional privilegiado, como preferimos para não adotar o rigor de Barnes) "na comparação com a região maior", capitaneada pela cidade de São Paulo. Este região seria, também, densa na "comparação" com o conjunto da rota. As imagens abaixo apresentam visualmente o argumento, ao demonstrar as diferentes camadas relacionais de Sorocaba a partir de diferentes escalas de observação.

A conclusão é a de que para a escolha de noivos, padrinhos e parceiros de crédito, o mercado relacional mais interessante (ou possível) era o local. A grande maioria dos negócios se dava dentro deste limite. Alguns agentes podiam ir um pouco além e manter negócios com localidades vizinhas; outros podiam ir bem mais além e tratar com regiões um pouco mais distantes. Mas mesmo os melhores intermediários das vilas que observamos tinham dificuldade de emprestar, tomar emprestado, casar, apadrinhas e cobrar dívidas com agentes das outras partes da rota mercantil. Assim, a idéia de "superfície mercantil homogênea", sugerida por Braudel ${ }^{28}$ para explicar como rotas de longa distância funcionavam, na realidade aqui estudada, não seria perceptível. A mesma restrição geográfica, matizada pelas distintas concentrações populacionais no espaço da América lusa, nos faz pensar em "comunidades onde a convivência, a vizinhança, a família e a amizade, assim como os conflitos, têm um peso extraordinário no acesso ao crédito". Se os dados acima nos sugerem que há uma densidade local que garante o suprimento de crédito até certo ponto, eles não nos falam sobre os conflitos locais e sobre as rupturas existentes em cada comunidade. Um cenário hipotético onde todos os habitantes de uma comunidade se conhecessem (o que não está muito longe de acontecer, ao menos entre as famílias) não significaria que todos confiassem em todos. Pelo contrário. Como indica Burt em seus trabalhos, há uma série de complicadores próprios de redes densas que impedem, em muitos casos, a criação de confiança ou sua manutenção. ${ }^{29}$

\footnotetext{
28 Braudel, 1998.

${ }_{29}$ Burt, 2001.
} 
Entendo confiança, ou crédito, conforme se usava na época, como o conceito que as pessoas têm umas das outras, um instrumento de medição, uma forma de classificar o comportamento social, avaliar quem eram os "homens de bem". Uma pessoa só pode ser confiável conforme é avaliada como tal por outro(s), ou seja, o uso do instrumento de medição vai variar de acordo com quem o usa, o que pode trazer resultados muito diversos, considerando que os recursos estão desigualmente distribuídos, especialmente as informações e os fatores que modificam as opiniões. E a própria circulação de opiniões diversas vai contribuir para modificar este cenário, num quadro dinâmico, que pode mesmo ser dinamicamente conservador. Todavia, a medida que devemos usar para isso não é a métrica. Deve ser uma medida semelhante à utilizada naquele momento. Deve ser equitativa, com uma medida própria para cada um.

Queremos atentar para a relevância deste procedimento e abordagem: tomando os dados desta maneira, podemos monitorar o alcance de certos agentes no espaço em questão. Se aceitarmos que a comunidade é densa, é relativamente mais fácil obter laços dentro desta. Tornar-se um mediador dentro da comunidade é significativamente mais simples que obter relações fora da comunidade. Por sua vez, tornar-se um mediador inter-regional é tarefa ainda mais árdua, especialmente fora do "cluster" imediato. Foi seguindo aqueles que tinham esta prerrogativa extra-local que pudemos compreender melhor como funcionava a confiança na rota mercantil em questão. Seguindo as idéias de autores como Burt, é possível acreditar que um mediador com condições de ir além de sua localidade teria mais benefícios e poderia obter mais recursos. Comecemos a ver isso mais de perto, ao seguir o rastro de dívidas ao longo do período e da rota mercantil. Convém um pouco de paciência e atenção, pois descrever uma nuvem densa de relações, com atenção ao lugar social de cada um, não é tarefa fácil. E vai requerer a atenção do leitor.

Em 1796, na Capela do Tamanduá, o Capitão Manuel Gonçalves Guimarães concedia a $250 \$ 000$ para o Capitão José Joaquim Mariano da Silva Cesar, a pedido do Doutor José Joaquim de Oliveira Cardoso. Estes recursos eram para o custeio de uma tropa que César conduzia. ${ }^{30} \mathrm{Em}$ meados de 1802, o filho de Manuel Gonçalves Guimarães, o Alferes Joaquim Gonçalves Guimarães, tomava $496 \$ 196$ de diversas pessoas através do Cofre dos Órfãos, instituição que reunia os ativos de órfãos e os administrava, inclusive emprestando numerário. No final daquele mesmo ano, Joaquim registrava em cartório uma venda fiada a José de Lima Pacheco, no valor de 451\$340, tudo em fazenda

${ }^{30}$ Biblioteca Nacional, Rio de Janeiro, Documentação da Casa Doada, Correspondências II-35, 25, 03-004. 
seca, provavelmente comprada com os recursos obtidos junto ao cofre e agora vendida para um terceiro. ${ }^{31}$

Uma família importante como os Gonçalves Guimarães de Curitiba ocuparam ao longo de poucos anos diferentes posições no mercado de crédito, ora como credor, ora como devedor, e sempre de valores expressivos. Vejamos o trajeto dos recursos: da mão de Manuel, os recursos foram para o Capitão Cesar, que gastou ao longo do caminho em produtos para manter os animais. Depois, da mão de diversos órfãos os recursos se concentraram na de Joaquim Gonçalves, que repassou o crédito para Lima Pacheco. Importante: Joaquim pagava juros ao longo de todo o tempo que fez os empréstimos ao Cofre. Enquanto isso havia oferecido a Lima Pacheco um prazo para pagamento sem juros.

E não pára por aí. Lima Pacheco havia falecido entre a compra e o registro em Cartório de sua dívida. Provavelmente Joaquim registrou o crédito, pois temia ser esquecido pelos inventariantes. Lima Pacheco não morreu pobre. Ainda em 1802 o Cofre dos Órfãos emprestava $100 \$ 000$ pertencentes à Maria, sua herdeira e em 1808 , mais $126 \$ 200$. Umas destas quantias, a de 1802 , foi para João da Silva Pereira, que em 1806 passava em Curitiba com sua tropa, talvez montada com recursos que fizeram tão longo caminho.

João Pereira Chaves devia muito dinheiro, quando do inventário de sua esposa, Gertrudes de Lima, em 1777. Entre seus credores, estavam alguns negociantes de peso na localidade, como José Guedes Luis, assim como gente do Rio de Janeiro, como José Rodrigues Ferreira, e criadores de animais da região, como Francisco José Martins. Somente para estes, ele devia 7:660\$800. Por outro lado, ele era credor de alguns dos mais poderosos homens do Continente do Rio Grande, tais como o Coronel Rafael Pinto Bandeira, o negociante e Capitão Manuel Fernandes Vieira, o Capitão Domingos de Lima Veiga e o Capitão-mor Manuel Bento da Rocha. Não posso dizer quando tais dívidas foram feitas, nem em que ordem. Mas de algum modo Pereira Chaves fez circular uma grande quantidade de recursos entre nomes poderosos na região e fora dela.

José Guedes Luis, um dos credores de Pereira Chaves, surgia, quatro anos depois, como devedor, no inventário de Eufrásia Maria da Conceição, esposa do Tenente Manuel Alves de Carvalho. O tenente, por sua vez, fora devedor de Francisco Xavier de Azambuja em 1769, que nesta ocasião era também credor de Rafael Pinto Bandeira e devia à Ventura Pereira Maciel e ao Padre Tomas Clarque. Não nos afastemos muito do Tenente Carvalho. Naquele

${ }^{31}$ Livros de Notas do Primeiro Tabelionato de Curitiba, Livro 27, págs. 71, 72, 73, 74 e 90, Arquivo do Centro de Documentação e Pesquisa de História dos Domínios Portugueses. 
mesmo ano de 1781, quando do inventário de sua consorte, ele era credor de boas quantias à diversas pessoas, entre as quais, João José Cherem, morador no Rio de Janeiro, Belquior de Arantes, da Vila de Lages e do tropeiro José da Silva, cuja dívida estava na mão de Paulino Aires de Aguirre, em Sorocaba, para ser cobrada. Entre estes também estava o Guarda-mor de Sorocaba, João de Almeida Leite, com quem pegamos uma carona para aquela vila.

O Guarda-mor Almeida Leite devia para Manuel Alves de Carvalho em 1781, mas era credor de Antonio Bicudo de Almeida quando este último foi inventariado, em 1791. Bicudo devia para muitas pessoas, mas era credor de outras tantas. Entre seus credores estavam o Capitão-mor Cláudio de Madureira Calheiros e Vicente José de Camargo. Entre os devedores, estava Anacleto de Souza Coutinho, que também devia para Paulino Aires de Aguirre e Andreza de Almeida Pacheco, assim como o Sargento-mor Francisco Ribeiro de Moraes, que era também devedor de Ana Maria de Anhaia, esposa de Antonio Leme Cavalheiro. Anhaia e Leme Cavalheiro, por seu turno, eram credores e devedores (simultaneamente) do Capitão-mor Calheiros, que fora credor de Salvador de Almeida Lara. Lara também devia para Antonio de Godoi Diniz que também devia para o Capitão-mor. Godoi Diniz também devia para Salvador de Oliveira Leme, que devia para seu genro, Paulino Aires de Aguirre, e era credor de Antonio Leme Cavalheiro.

Acabamos de verificar algumas cadeias de crédito que se estendiam pelo caminho das tropas, mas que se concentravam nas localidades. Mais interessante, contudo, é o fato de que na maior parte dos casos, "a obtenção de recursos não significa acumulação, mas circulação". Um sujeito poderia obter recursos e tempos depois acaba repassando aqueles importes. Isso tudo faz chamar a atenção para dois problemas que quero aqui discutir: 1) a volatilidade dos recursos, sua rápida circulação, que faz com que não permaneçam entesourados; 2) a "existência de diferentes camadas de densidade relacional, o que faz os recursos circularem com ritmos e modos diversos ao longo da rota".

A comparação com estudos semelhantes pode ajudar na compreensão deste cenário. Ana Crespo, em seu estudo sobre os negociantes que atuavam no comércio atlântico espanhol, também destaca a importância das escalas como instrumento para compreensão destas redes de mercadores. ${ }^{32}$ Há diferenças significativas entre os dois contextos. No comércio atlântico espanhol, encontramos uma vasta gama de negociantes, com origens sociais, geográficas e culturais (religiosas, inclusive) convivendo cotidianamente e intensificando seus contatos comerciais pela convivência diária na Praça de Cádiz, onde estavam sediadas as principais companhias que se lançavam ao oceano. No

${ }^{32}$ Crespo Solana, 2012. 
caso que apresentamos, procuramos demonstrar como as possibilidades de encontro e de intensificação dos contatos cotidianos eram escassas e disponíveis somente para alguns. A base disponível para a construção da confiança era a hierarquia social: quanto mais prestigiosa a pessoa, mais recursos e mais crédito poderia obter, mesmo de desconhecidos, pois suas prerrogativas sociais já seriam suficientes.

Também interessante é o quadro apresentado por Biagio Salvemini, ao estudar pequenos mercadores no final do século XVIII na Puglia, dando especial atenção às formas orais de circulação de informações, em um contexto onde boa parte daqueles pequenos mercadores era analfabeta. A relevância de seu estudo reside no fato de priorizar um pequeno mercado obscurecido por outras grandes rotas do Adriático, onde os pequenos negociantes precisavam articular redes muito sólidas e densas para fazer sobreviver diante de companhias bem estabelecidas. O problema é que ele apresenta um cenário de grande homogeneidade na circulação de informações dentro das redes daqueles "marinheiros". A informação circulava entre os portos do Adriático com "estrema facilita". Neste caso, restaria indagar sobre aquilo que não circula com facilidade. Aquelas informações que poucos têm acesso e que distinguem uns negociantes dos outros, contribuindo para a peculiar hierarquização que marcava a vida daquela gente. ${ }^{33}$

\section{Sobre AS REDES DE LONGO ALCANCE E SEUS AGENTES}

Os casos que apresentamos nos permitem verificar a dinâmica das relações, mas não como alguém se torna um broker inter-regional. Procuraremos tratar agora de algumas redes densas que "uniam os pontos", ou seja, articulavam as diversas localidades à margem do caminho das tropas e outras. Vimos que havia uma tendência bastante grande, na maior parte das localidades da rota, para se buscar um parceiro relacional (noivos, padrinhos, sócios, amigos) na mesma localidade onde cada agente atuava. Entretanto, algumas pessoas conseguiam construir e manter relações que rompiam barreiras regionais e permitiam a realização de empreendimentos de vulto superior aos permitidos nas localidades, como o Tenente Manuel Alves de Carvalho, que vimos acima. Para tanto, vamos explorar as ligações de alguns importantes grupos familiares do caminho das tropas e suas ligações extra-regionais.

Comecemos com o comportamento da família de Paulino Aires de Aguirre, homem poderoso em Sorocaba. No início da década de 1780, Paulino fazia

33 Salvemini, 2007. 
sociedade com José Vaz de Carvalho e Francisco Rodrigues de Macedo e, juntos, arrematavam o Contrato dos Dízimos da Capitania de São Paulo, no valor de 61:100\$000. No mesmo ano, Paulino arrematava também os Meios Direitos de Curitiba, no valor de 31:220\$000, os direitos do Registro das Canoas, no valor de 1:000\$000, os direitos da Passagem do Rio Curitiba, avaliado em 260\$000 e os direitos da Entrada das Minas, de 250\$000, mas, neste últimos, em sociedade com Manuel de Oliveira Cardoso. ${ }^{34}$

Quem eram os sócios de Paulino? José Vaz de Carvalho vinha de Portugal, do Aveiro, formado pela Universidade de Coimbra, chegando em São Paulo em 1774 onde logo se casou com a filha de um importante mercador local, também de origem lusa, Manuel de Macedo, que já havia falecido, e de Escolástica Maria de Matos, unindo-se, assim, a um importante grupo de negociantes de São Paulo. Em 1786, junto com Paulino, arremata os Dízimos, onde vão permanecer por muitos anos. ${ }^{35} \mathrm{Em} \mathrm{1798,} \mathrm{não} \mathrm{sabemos} \mathrm{se} \mathrm{antes} \mathrm{ou} \mathrm{depois} \mathrm{da}$ morte de Paulino, Carvalho, juntamente com novos sócios, José Arouche de Toledo Rendon, Luis Antonio de Souza e José Manuel de Sá, fazem novo lance que eleva o valor dos Dízimos de 61:100\$000 para 89:200\$000, vencendo, assim a disputa com negociantes reinóis que tinham interesse neste estanco.

Em 1806 ele escreveu à Sua Majestade pedindo remuneração por seus serviços, argumentando, entre tantas realizações, o fato de que "tem o suplicante tratado-se a lei da nobreza como honrado cidadão e compreendido na mercê de Fidalgo, cavaleiro que concedeu o Augustíssimo Senhor Dom João V [...] aos que na dita Cidade de São Paulo servissem de Juízes Ordinários e vereadores. ${ }^{36}$

O outro sócio, Manuel de Oliveira Cardoso, era Capitão-mor de São Paulo. Manuel já era arrematador dos direitos do Novo Registro de Lages. ${ }^{37}$ Em 1786, participa de todos aqueles rendimentos junto com Paulino e, paralelamente, é o procurador de Conselheiro Ultramarino Corte Real para a administração dos Meios Direitos da Casa Doada. Seu filho natural, José Joaquim de Oliveira Cardoso, se tornaria Desembargador em São Paulo, anos depois. ${ }^{38}$ Mesmo com a morte de Manuel de Oliveira Cardoso, em meados da década de 1790, Paulino vai seguir atuando nas arrematações ao lado de José Vaz de Carvalho, de Francisco José de Sampaio Peixoto e de Manuel da Silva Reis, Capitão-

${ }^{34}$ Correspondências, Arquivo Histórico Ultramarino (AHU), Projeto Resgate. Documentação da Capitania de São Paulo, Acervo Mendes Gouveia, Acervo "Avulsos" (SPMG), 3136.

35 Araújo, 2008.

${ }^{36}$ Correspondências, AHU, SPMG, avulsos, 1223.

${ }^{37}$ Ibidem, 2975.

38 Ibidem, 3159. Manuel reconhece oficialmente seu filho em 1784 e indica ter pago os estudos no Rio de Janeiro e em Coimbra. 
mor de Guaratinguetá. ${ }^{39}$ Em 1797, o quarteto arremata os "Novos Impostos de São Paulo e todas as vilas", no valor de 18 contos de réis, além dos Meios Direitos de Curitiba, no valor de 34 contos. $^{40}$

Paulino fez também diversos negócios dentro de seu núcleo familiar, especialmente com seu sogro e seu genro, Antonio Francisco de Aguiar, que lhe sucedeu na administração dos direitos de Sorocaba. Da mesma forma, seus sócios também alternaram entre o local e o regional: José Vaz de Carvalho atuava junto com Sampaio Peixoto, que acabou se integrando a sua família ao se casar com sua filha. Além disso, logo que chegou à capital, Carvalho logo se integrou a um denso grupo de negociantes daquela localidade. Também Manuel de Oliveira Cardoso articulava negócios dentro da família simultaneamente a empreendimentos com não familiares e pessoas de outros espaços. Ele era procurador de Tomé da Costa Corte Real, em Lisboa, senhor da "Casa Doada". E para dar conta desta administração, da qual estava encarregado, se valia de seu sobrinho Francisco de Paula Teixeira. ${ }^{41}$

Por seu turno, o Capitão-mor de Guaratinguetá, Manuel da Silva Reis, também foi arrematador dos direitos do Rio Paraíba, ${ }^{42}$ junto com José Dias dos Santos, vereador e Capitão de Milícias em Lorena, vila vizinha da qual o próprio Silva Reis fora Capitão-mor, em caráter excepcional, e na qual mantinha interesses. ${ }^{43}$ Silva Reis atuou em concordância com as Câmaras de Lorena e Guaratinguetá, além de ter o apoio do governador e de outros membros da elite local, tudo em função dos abusos atribuídos ao Sargento-mor de Lorena, Antonio Lopes de Lavre. Importa ressaltar, ainda que José Vaz de Carvalho e Manuel da Silva Reis eram vizinhos, em fazendas que tinham em Guaratinguetá, ${ }^{44}$ além de sócios.

A rede da qual Paulino Aires de Aguirre fazia parte funcionou eficientemente entre o início dos anos 1780 e os anos 1800 pelo menos. Mas ele faleceu em 1798, sem que isso tenha comprometido os alinhamentos entre os demais aliados. Paralela à rede de Paulino, nos anos 1790, havia outra, que de algum modo se inseria naquela, a de Antonio Francisco de Aguiar. Aguiar era genro de Paulino e membro relevante dentro do arranjo familiar. Após a morte de Paulino, a família não perde a totalidade de seus vínculos, mas os investimentos relacionais sofrem alguma alteração. A família perde, parcialmente, a proximi-

39 Ibidem, 3316.

40 Ibidem, 3477.

${ }^{41}$ Correspondencias da Casa Doada. Biblioteca Nacional - BN-35,25,25-27. BN$35,25,17$. BN-35,25,03.

${ }^{42}$ Correspondencias, AHU, SPMG, 3136.

${ }^{43}$ Ibidem, 3316.

44 Ibidem, 3011. 
dade com o núcleo de sócios que participava ativamente das arrematações, mas direciona seu foco para uma política de relações muito mais vasta.

Sendo administrador do Registro de Sorocaba e da "Casa Doada", ele devia regularmente enviar barras de ouro e prata, além de dinheiro de contado, para São Paulo, tarefa para a qual não dispunha de ajudantes. Um grupo, que somou cerca de vinte pessoas, ajudava na administração da "Casa Doada", sem receber nenhuma remuneração. Era um seleto grupo que contava com a total confiança de Aguiar, e que era encarregado de levar os ricos malotes de Sorocaba para São Paulo, de onde partiriam para Santos e daí para Lisboa. É com base nestes sujeitos que faremos a análise da rede de Antonio Francisco. É certo que é um procedimento muito diverso daquele que utilizamos para observar as relações de Paulino, mas em ambos os casos, é o material que disponho e com ele se pode fazer muita coisa.

Este pequeno grupo de "portadores" voluntários vinculados a Antonio Francisco de Aguiar era uma fração bastante prestigiosa. O maior portador era o Padre Manuel Caetano, filho do Capitão Francisco Luis de Oliveira, que havia sido vereador em Curitiba em 1780. O segundo maior emissário de valores de Antonio Francisco, em termos monetários, foi seu cunhado, o Capitão-mor de Sorocaba, Salvador de Oliveira Aires. O terceiro colocado, também em termos monetários, José Fernandes Nunes, era vereador em São Paulo em 1797, além de ser Tenente-Coronel. Do quarto, Antonio de Godoi Diniz, sabemos que era "mercador de loja", no que tinha ganho, em 1801, cerca de 1 conto de réis e possuía doze cativos. Do quinto, Américo Antonio Aires, já era Capitão de Milícias havia alguns anos quando fez sua primeira remessa de valores a pedido de Aguiar, além de ser seu parente próximo. Dentre os demais estavam o Capitão Bento José Leite Penteado, o compadre e Coronel Francisco Xavier dos Santos, o Coronel Bento Manuel de Almeida Pais, o sogro e Tenente-Coronel Paulino Aires de Aguirre, o Capitão Domingos Inácio de Araújo, o Cirurgião-Mor Manuel Magalhães dos Santos Rego, o vereador em São Paulo, João Lopes França e o Alferes José Correia de Toledo.

Destaca-se neste seleto grupo, que gozava da mais alta confiança do administrador Aguiar, uma preferência pelos vínculos de parentesco. Mas o que é mais saliente é o elevado nível hierárquico dos homens confiáveis de Aguiar, a grande maioria deles com altos postos militares e quase sempre lideranças locais. Note-se que o critério para a seleção deste grupo, feito por Aguiar e por mim adotado, era de pessoas confiáveis e aptas para conduzir valores de Sorocaba para São Paulo, ou seja, além de reputadas aos olhos de Paulino, deveriam ter, casualmente, uma viagem programada para a capital, mais ou menos no momento em que Aguiar tivesse dinheiro em caixa. Isso deve conduzir a uma grande concentração de sorocabanos e paulistanos nesta 
seleção, como de fato acontece. Ainda assim, pudemos identificar um vínculo que chegava até Curitiba, através do padre Manuel Caetano e seu pai. Afora isso havia o Capitão-Mor de Itapetininga, seu aparentado, além de José de Andrade, que era amigo de Aguiar e capitão em Taubaté. Os gráficos abaixo apresentam as posições destes agentes nas suas transações com Aguiar.

Ainda estamos no campo de visão mais restrito de Antonio Francisco de Aguiar. Se ampliarmos um pouco a análise da rede, veremos que ela atinge diversas localidades bem distribuídas geograficamente, chegando com força à Itapetininga, Curitiba e Taubaté. Domingos Inácio de Araújo, por exemplo, era o procurador de Manuel Gonçalves Guimarães, que era tenente-coronel naquela praça. Para além das relações de Aguiar, havia a própria unidade arrecadadora de Curitiba, onde Manuel José Correia da Cunha fazia seu trabalho e criava suas relações. Em Santos havia, igualmente, parte do aparato da Casa Doada, representado pelo irmão de Antonio Manuel Fernandes da Silva, Luis Pereira Machado. Mas antes de nos determos nestes contatos, vejamos um pouco mais a projeção espacial e demográfica da rede de Aguiar.

Figura 12. Rede de Antonio Francisco de Aguiar (INCLUINDO APENAS OS “PORTADORES" DE REMESSAS)

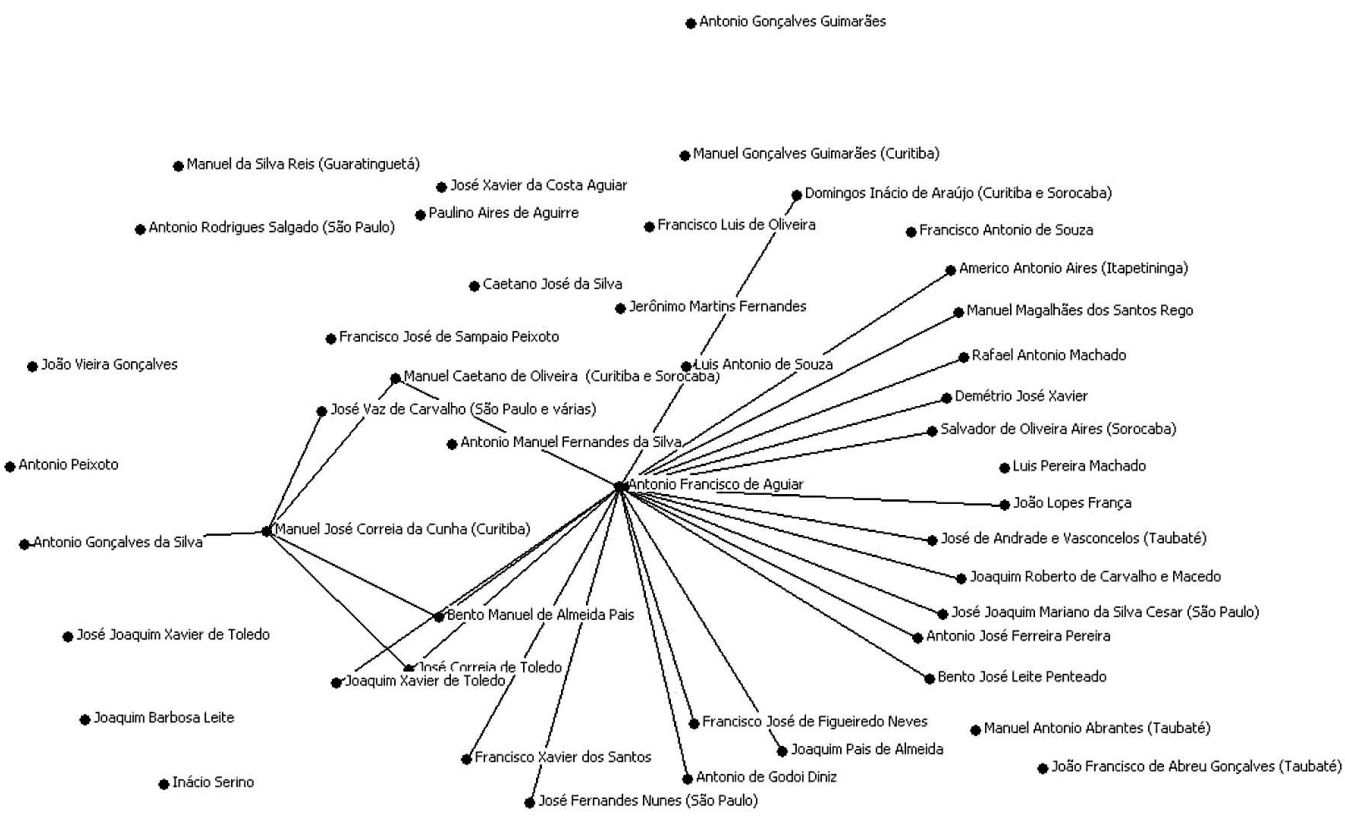

Fonte: BN-II-35, 25, 25-27. 


\section{Figura 13. Rede de Antonio Francisco de Aguiar (INCLUINDO PORTADORES E OUTRAS ALIANÇAS)}

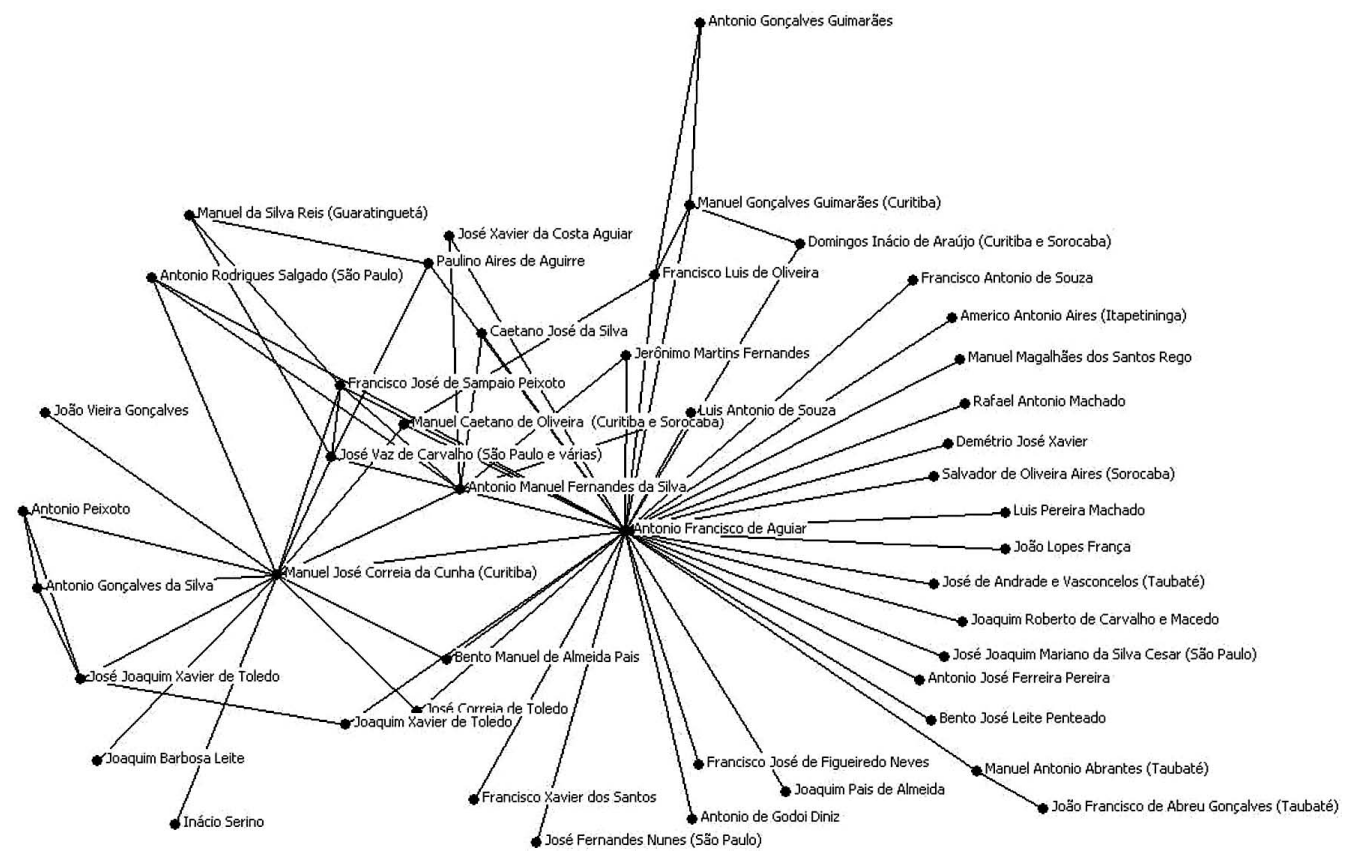

Fonte: BN-II-35, 25, 25-27.

Devemos considerar que cada um daqueles personagens, secundários na rede de Aguiar, tinha por sua vez suas próprias redes, de diferentes densidades, em diferentes localidades. Se medirmos o impacto demográfico, apenas com estes vínculos com as elites locais destas localidades ele teria condições de atingir indiretamente um contingente populacional enorme em um espaço bastante estendido. Esse impacto se amplia se considerarmos o peso dos capitães nas diversas regiões onde atuavam, seus recursos locais, suas parentelas, escravarias e relações. $\mathrm{O}$ leque de relações de Aguiar se amplia apenas se considerarmos pontualmente algumas de suas relações. Importante negociante da capital, José Vaz de Carvalho tinha negócios em Taubaté e Curitiba, além de outras localidades do interior. Era arrematador dos meios direitos de Curitiba, dos direitos do Registro de Cima da Serra e dos "novos impostos" de toda a Capitania de São Paulo.

Some-se a isso a própria circulação no Registro de Sorocaba, onde Antonio Francisco tomava contato com diversos tropeiros, podendo criar ou reforçar laços pretéritos ou apenas tomar informações. Entre os tropeiros, encontramos diversos que ocupavam postos de poder local em diversas comunidades da 
Capitania de São Paulo. Antonio Ribeiro de Andrade era oficial da Câmara de Curitiba e Capitão-mor da Freguesia de São José, na mesma vila. Também fora vereador em Curitiba Estevão José Ferreira e Manuel Soares do Vale. Eleutério da Silva Prado fora vereador em Jundiaí, assim como Francisco Martins do Monte e José Mariano de Oliveira. Veríssimo José Gomes fora vereador em Paranaguá, além de pertencer ao Regimento de Cavalaria de Curitiba. José Carneiro Lobo era da Câmara de Castro onde sua família tinha grande importância. Antonio da Cunha Fortes era Oficial da Câmara de Pindamonhangaba e na mesma instituição, em Mogimirim, estiveram Joaquim de Morais Bueno e Demétrio José de Macedo. Em Lages, Antonio José Pereira era Juiz presidente da Câmara e alferes da Cavalaria Miliciana local.

É certo que, como nos indica Nuno Monteiro, as Câmaras de localidades periféricas não tinham o mesmo significado dos conselhos municipais de grandes localidades, como o do Rio de Janeiro no final do XVIII ou de Lisboa. De qualquer modo, não deixava de ter alguma importância numa sociedade sem hierarquias institucionais (tais como a diferença entre nobreza e terceiro estado), onde pertencer a uma Câmara, à Misericórdia ou deter algum posto de comando já significava algum prestígio e distinção. ${ }^{45} \mathrm{E}$, como vimos, diversos destes sujeitos ocupavam igualmente postos militares e políticos em suas localidades. Pude encontrar ao menos 44 tropeiros referidos com postos militares ou eclesiásticos, dos quais se destacam 14 capitães, 12 tenentes, 5 alferes, 4 padres e 4 tenentes coronéis. Não estamos querendo dizer, com isso, que tivessem algum relacionamento com Aguiar e seus amigos da Casa Doada apenas por passar no Registro. O que queremos dizer é que esta atividade propiciava um "meio ambiente" favorável para o contato entre as elites regionais, favorecia a criação de uma densidade deste grupo.

Observando os negócios e o raio de alcance de Antonio Francisco de Aguiar e seus parceiros da Casa Doada, não apenas da administração da mesma unidade arrecadadora, mas das próprias "oikonomias" de seus membros (estas coisas se confundiam) percebemos que há certa circunscrição espacial, um limite geográfico um tanto borrado, mas perceptível. Na medida em que saímos da zona formada por São Paulo, Sorocaba, Jundiaí, Santos e Curitiba, a presença daqueles administradores vai se diluindo. Em direção ao sul, por exemplo, já em Lages anda apagada para escurecer-se ainda mais nos Campos de Cima da Serra e finalmente se apagar em Viamão, onde tinham pouco alcance. Mesmo em Curitiba o brilho não era o mesmo que em Sorocaba e São Paulo. Para o norte, pouca força dispunham nas Minas e mesmo no Rio de Janeiro. Em termos locais era uma elite importante e densa, mas sem um alcance muito maior. De

${ }^{45}$ Boxer, 2000. Russell-Wood, 1981. 
qualquer maneira, o espaço de atuação de Aguiar era imenso, e particularmente privilegiado para poder, entre outras coisas, monitorar tropeiros e cobrá-los.

Em outro trabalho concluímos que a elite do Rio Grande de São Pedro, capitania mais ao sul, apesar de forte naquela região, não dispunha de força em outros espaços e não buscava disputar territórios, apesar de investir em relações com outras elites regionais. For por isso que Evaristo Pinto Bandeira, importante membro de uma das mais fortes facções da elite local, casou-se com Cristina, da família Pacheco de Miranda, importantes negociantes de animais da região de Curitiba. Isso nos faz pensar que as elites do centro sul do Estado do Brasil tinham sua densidade maior na localidade e apenas estendiam seus laços junto a outras elites regionais. A principal costura era com os grupos que constituíam sua base social e com seus vínculos familiares mais próximos (e em ambos os casos havia relações ainda mais densas). Um "arremate" ligava as diferentes elites regionais, feito a partir de negócios e parentescos. Hipoteticamente, para um membro da elite de Sorocaba acessar um peão em Viamão, lançaria mão de uma rede de contatos através das elites regionais até a elite viamonense, que rapidamente teria como localizar aquele peão em sua densidade local. ${ }^{46}$

Aqui não basta a noção de escala geográfica, ainda que esta seja fundamental. ${ }^{47}$ Certas redes densas dentro de escalas locais (famílias) coincidiam com redes de longo alcance, em escalas quase continentais, como o conjunto da amostra, toda a região sul da América Portuguesa. E mesmo a utilização do conceito de "redes" precisa ser pensada de uma forma dinâmica. As redes não são simplesmente a base por onde os negócios fluem, as conexões que garantem coerência ao circuito mercantil. ${ }^{48}$ Elas são gestadas e modificadas todo o tempo em função destes mesmos negócios, podendo, muitas vezes, ser criadas por elementos externos, digamos assim, como valores sociais, relações políticas e culturais. Como pudemos ver a noção de hierarquia social, manifesta no respeito às patentes militares, garantiu uma grande quantidade de negócios e "não por todos se conhecerem", mas porque "todos se reconheciam" como figuras socialmente prestigiosas e dignas de confiança. A família era, igualmente, uma base segura, mas não universal. Se isso fazia sentido para a camada local, onde todos eram identificados com seus núcleos domésticos, na camada "maior", com escala continental, este atributo se diluía e dependia do quão prestigiosos eram os parentes ${ }^{49}$.

\footnotetext{
${ }^{46}$ Gil, 2007.

47 Crespo Solana, 2012.

${ }^{48}$ Idem.

49 Fernandez Perez, 1997.
} 


\section{Conclusão}

Era nestes laços intra-elites regionais que estava um dos pontos chave da reprodução das próprias elites. Além do fato de que "elas se reconheciam mutuamente", eram estas alianças que favoreciam a aquisição de informação e permitiam um maior controle social, o que contribuía para a manutenção daquela ordem. Neste sentido, as elites regionais atuavam na mediação dos contatos inter-regionais e garantia assim uma recepção privilegiada daqueles recursos advindos do controle da informação. Eram eles que alinhavavam os pequenos retalhos da grande colcha que parecem ser os territórios do sul da América. Afinal, eram estes sujeitos que tornavam homogêneas as superfícies mercantis. Braudel, afinal, estava certo também neste caso.

É claro que a informação e o controle social também estavam, digamos, disponíveis para os estratos mais baixos daquela sociedade, mas num nível muito local. Podemos ainda avançar nesta hipótese e argumentar que este mesmo panorama se dava em uma escala menor, dentro das próprias localidades, intra-bairros, o que permitia a saliência de outros "mediadores", menores, mas igualmente importantes no costura social. Tais relações se constituíam nos principais recursos daqueles homens e mulheres. No caso da rota, o superficial dos laços fracos é coberto pela noção de hierarquia naturalizada e pela noção de família.

Este modelo permitia uma concentração de poder crescente. Da maneira como descrevemos, com as elites locais estabelecidas e tendo prioridade nos contatos com as demais, tal parece iniciar-se nas no último quartel do XVIII. Antes disso não percebemos, especialmente no Rio Grande, uma consolidação visível dos arranjos de poder local, dinamizados durante e após as guerras de reconquista. Da mesma forma, os mesmos conflitos favoreceram grupos na Capitania de São Paulo, como o próprio Antonio Francisco de Aguiar e sua família. O comércio dos muares reforçou este cenário, permitindo a comunicação e o enriquecimento.

Para concluir, acreditamos que a idéia de adotar uma noção de densidade imprecisa e imperfeita, construída a partir de fontes não previstas para tal, tendo em conta diferentes escalas de observação, pode ser uma ferramenta importante para compreender de que forma se moldavam as relações de crédito em economias modernas, ou melhor, quais eram os limites relacionais daquelas economias. No caso aqui exposto, vimos que o uso dos batismos e casamentos permite medir grosseiramente os limites espaciais e sociais (nesta ordem) das relações de uma comunidade, na falta de fonte melhor. As dívidas permitiram observar duas concentrações diferentes de laços dentro da mesma comunidade, sem considerar o espaço, mas considerando aspectos mais propriamente econô- 
micos, com atenção ao papel dos negociantes locais e regionais. Acreditamos, assim, que a utilização da idéia de diferentes "camadas" de relacionamentos, visíveis em diferentes escalas de observação, se apresenta como uma opção metodológica adequada para trabalhar com a noção de densidade, mesmo em circunstâncias onde as fontes não são as usuais.

Por fim, é importante destacar como esta metodologia permitiu observar alguns elementos relevantes, particularmente, a forma como os recursos fluíam (sem se concentrar em poucas mãos) através de relações sociais baseadas em valores como família e hierarquia social. Ao adotar a noção de "camada", pudemos observar que os negócios mais recorrentes eram os locais, fenômeno propiciado pela interação cotidiana nas localidades ao longo da rota. Poucos agentes podiam ir além de suas paróquias, alcançando o conjunto da rota, em um contexto no qual as informações eram escassas e valiosas. Neste universo, dispor de uma patente militar se revelava fundamental na busca pelo prestígio que poderia garantir o crédito necessário para comprar animais em outras e mais distantes partes do caminho.

\section{BIBLIOGRAFIA}

Araújo, M. L. V., José Vaz de Carvalho, contratador da capitania de São Paulo, Simpósio de Pós-graduação em História Econômica (ed.), São Paulo, ABPHE, 2008: 23-35.

Bacellar, C. d. A. P., Os senhores da terra, família e sistema sucessório de engenho no oeste paulista, 1765-1855, Campinas, CMU/UNICAMP, 1997.

Bacellar, C. d. A. P., Viver e sobreviver em uma vila colonial (Sorocaba - século XVIII e XIX), São Paulo, Fapesp/Annablume, 2001.

Barnes, J. A., "Graph theory and social network, a technical comment on connectedness and connectivity", Sociology, 03 (Oxford, 1969a): 215-232.

Barnes, J. A., "Networks and political process", J. C. Mitchell (ed.), Social Networks in urban situations, Analysis of personel relationships in Central Africa Towns, Manchester, The University Press, 1969b: 51-76.

Barth, F., Process and form in social life, London, Routledge \& Keagan Paul, 1981.

Barth, F., O Guru, o iniciador e outras variações antropológicas, Rio de Janeiro, Contracapa, 2000.

Bott, E., Família e rede social. Papéis, normas e relacionamentos externos em famílias urbanas comuns, Rio de Janeiro, Francisco Alves, 1976.

Braudel, F., Civilização material, economia e capitalismo, os jogos das trocas, São Paulo, Martins Fontes, 1998. 
Burmeister, A. M., “A Nupcialidade em Curitiba no século XVIII”, História, Questões e Debates, 02/02 (Curitiba, 1981): 63-68.

Burt, R., "Bandwidth and Echo, trust, information, and gossip in social networks" A. Cassella \& J. Rauch (eds.), Networks and Markets, contributions from Economics and Sociology, New York, Russel Sage Fundation, 2001: 30-74.

Burt, R., Brokerage and Closure. An introduction to social Capital, Oxford, Oxford University Press, 2005.

Clavero, B., Antidora. Antropologia catolica de la economia moderna, Milano, Giuffrè Editore, 1990.

Crespo Solana, A., "Self-organizing: the case of merchant's cooperation in the Hispanic Atlantic economy (1680-1778)" Journal of Knowledge, Management, Economics and Information Technology, V/Special Issue (2012): 191-224.

Dedieu, Jean Pierre, "Les grandes bases de données: une nouvelle approche de l'histoire sociale. Le système Fichoz", Revista da Facultade de Letras- História, 05 (Porto, 2004): 101-114.

Epstein, A., "The Network and Urban Social Organization” J. C. Mitchell (ed.), Social Network in Urban Situations, Manchester, Manchester University Press, 1969: 29-62.

Fernández Pérez, P., El rostro familiar de la metrópoli: redes de parentesco y lazos mercantiles en Cadiz, 1700-1812, Madrid, Siglo XXI, 1997.

Fragoso, J.; Bicalho, M. F. \& Gouvêa, M. d. F., O Antigo Regime nos Trópicos, a dinâmica imperial portuguesa (séculos XVI-XVIII), Rio de Janeiro, Civilização Brasileira, 2001.

Gil, T., Infiéis transgressores, elites e contrabandistas nas fronteiras do Rio Grande e do Rio Pardo (1760-1810), Rio de Janeiro, Arquivo Nacional, 2007.

Granovetter, M. S., “The Strength of Weak Ties”, American Journal of Sociology, 78/06 (Chicado, 1973): 1360-1380.

Hanneman, R. A., Introduccion a los métodos del analisis de redes sociales, Riverside, Universidad de California Riverside, 1998.

Kühn, F., "Gente da fronteira, família, sociedade e poder no sul da América Portuguesa - século XVIII” (Tese de doutorado), Niterói, PPGHIS, UFF, 2006.

Levi, G., Centro e periferia di uno stato assoluto, Torino, Rosenberg \& Sellier 1985.

Levi, G., A Herança Imaterial, trajetória de um exorcista no Piemonte do século XVII, Rio de Janeiro, Civilização Brasileira, 2000.

Martins, M. F. V., A velha arte de governar, um estudo sobre politica e elites a partir do Conselho de Estado (1842-1889), Rio de Janeiro, Arquivo Nacional, 2005.

Salvemini, B., "Far negozio senza informazioni. 'Marinai' pugliesi nell'adriatico settecentesco" Quaderni Storici, 124/ 01 (Bologna, 2007): 155-203. 
Santili, D., "Representación gráfica de redes sociales. Un método de obtención y un ejemplo histórico", Mundo Agrario. Revista de estudios rurales, 06 (La Plata, 2003).

Weber, M., Economia e sociedade, Brasília, Editora UnB, 1999.

Fecha de recepción: 22 de febrero de 2013.

Fecha de aceptación: 4 de julio de 2013.

\section{Redes y capas de relaciones en la economía: metodologías para el estudio de la confianza mercantil en la América Portuguesa del Antiguo Régimen}

El objetivo de este trabajo es explorar la posibilidad de considerar las diferentes densidades de relación que estarían asociadas con diferentes grados de interacción y confianza, en la región meridional de la América portuguesa del siglo XVIII. Para llevar a cabo esta investigación, utilizamos distintas fuentes, entre ellas, los inventarios, los registros bautismales y las correspondencias. Para el estudio de este tema, ha sido creada una base de datos centrada en las relaciones e interacciones sociales. Los resultados indican una aproximación entre la densidad de las relaciones y la confianza.

Palabras Clave: redes sociales; economía del Antiguo Régimen; confianza; América Portuguesa.

\section{Relationship Networks and Layers in Economics: Methodologies to Study Trade Confidence in Old-Regime Portuguese America}

This paper explores how far different relationship densities can be associated with varying degrees of interaction and confidence in the southern part of eighteenth-century Portuguese America. Sources include probate inventories, parish records and letters. A database focused on relationships and social interactions has been created for this purpose, and our conclusions indicate a close relationship between relationship density and trade confidence.

KeY words: social networks; Old regime economy; confidence; Portuguese America. 